\title{
ADMINISTRATIVE REVIEW OF THE TREATY OF WAITANGI SETTLEMENT PROCESS
}

\author{
Jessica Andrew*
}

This paper looks at administrative review of the negotiation and settlement process for Treaty of Waitangi historical claims. The foundation is an analysis of the current treatment of these claims within the political arena, the Waitangi Tribunal and the courts. This includes a detailed analysis of the effectiveness of political and Waitangi Tribunal responses, and a hard look at the validity of the courts' continued stance that Treaty settlement cases are non-justiciable.

Due to the non-binding nature of its recommendations, the effectiveness of the Waitangi Tribunal depends largely on the existence of political buy-in from the Executive and political branches of government. Analysis of the evidence illustrates that this buy-in is lacking. Despite the intensity of Waitangi Tribunal scrutiny in this area, very few meaningful outcomes are being achieved.

Finally, the discussion of the courts' response to Treaty settlement claims looks closely at the concept of non-justiciability and the courts' continued application of broad precedents without meaningful analysis. This paper argues that a thorough understanding of the cases brought before the courts illuminates differences between those precedents being applied and the cases now being heard. Declaring a case non-justiciable has serious consequences and should not be done lightly.

\section{INTRODUCTION}

...the settlement of historical claims is not to pay off for the past, even were that possible, but to take those steps necessary to remove outstanding prejudice and prevent similar prejudice from arising; for the only practical settlement between peoples is one that achieves a reconciliation in fact. ${ }^{1}$

New Zealand has pinned many of its hopes for meaningful reconciliation of the issues facing Māori on the current process of negotiation and settlement of historical claims arising under the

* Submitted as part of the LLB(Hons) programme at Victoria University of Wellington.

1 Waitangi Tribunal The Taranaki Report: Kaupapa Tuatahi: Wai 143 (GP Publications, Wellington, 1996) 315 . 
Treaty of Waitangi. However, what has only recently come to the public's attention is the fact that the current process of negotiation of settlements faces a number of significant challenges it is currently unable to effectively deal with. The result is significant prejudice to affected Māori groups. The perpetuation of these issues and the continued utilisation of flawed processes by Crown administrators raise a number of serious questions about effective accountability under the Treaty of Waitangi, including the Crown's ability to properly meet its obligation of active protection.

This paper is an analysis of the treatment of Treaty settlement issues within the three main areas of review: the Waitangi Tribunal, the courts, and the political arena. What this should not be taken for is a review of the appropriate forum for the claims of Māori and indigenous peoples generally to be heard. ${ }^{2}$ Rather, this is a specific discussion of where issues that arise as a result of the existing Treaty settlement policy should be reviewed. This paper looks at the impact of the Executive's actions on the rights and interests of Māori. As famously analogised by Cohen, issues of indigenous rights are the miner's canary in democratic accountability: a failure to effectively protect indigenous interests indicates fundamental failures in the democratic and political processes. ${ }^{3}$ By analysing the government's responses within this limited but crucial area, it is possible to achieve a broader analysis of democratic accountability mechanisms both generally and within the constitutional milieu of the Treaty of Waitangi.

After providing background to the New Zealand Treaty of Waitangi context, this paper focuses on a detailed analysis of the Waitangi Tribunal's role within Treaty settlement review. This includes an examination of the impact of Waitangi Tribunal review. Following from this is a study of the courts' response to these issues, in particular the legitimacy of their repeated rejection of these claims as non-justiciable. Finally, this paper concludes by scrutinising the acceptability of the current state of affairs within our constitutional framework.

2 There is some excellent literature on this topic, particularly in the Canadian context. See Catherine Bell and Michael Asch "Challenging Assumptions: The Impact of Precedent in Aboriginal Rights Litigation" in Michael Asch (ed) Aboriginal and Treaty Rights in Canada: Essays on Law, Equality, and Respect for Difference (UBC Press, Vancouver, 1997) 38; Kerry Wilkins Advancing Aboriginal Claims: Visions/Strategies/Directions (Purich Publishing Ltd, Saskatoon, 2004); Joseph Eliot Magnet Litigating Aboriginal Culture (Juriliber, Edmonton, 2005).

3 Felix S Cohen "The Erosion of Indigenous Rights, 1950-1953: A Case Study of Bureaucracy" (1952-53) 62 Yale LJ 348, 390. 


\section{TREATY OF WAITANGI}

New Zealand is relatively unique in having one central constitutional document that largely governs the relationship between the Crown and Māori, the indigenous peoples of New Zealand. ${ }^{4}$ This document is Te Tiriti o Waitangi, or the Treaty of Waitangi (the Treaty).

Signed on 6 February 1840, the Treaty guaranteed Māori the right of "te tino Rangatiratanga o rātou whenua o rātou kāinga me o rātou taonga katoa" ${ }^{5}$ (unqualified exercise of their chieftainship over their lands, villages, and all their treasures) ${ }^{6}$ in return for the Crown gaining "kāwanatanga" 7 (complete government). ${ }^{8}$ It is a compact that allows the Crown the right to govern, while preserving Māori control over their land and treasures.

Due to the differences between the English and Māori texts of the Treaty and the lack of detail in the document itself, interpreting the Treaty is a difficult task. ${ }^{9}$ In order to help overcome the resulting difficulties in applying the Treaty, a number of principles have been developed. They are an attempt to clarify the rights and obligations of each of the Treaty partners. ${ }^{10}$ Although the Waitangi Tribunal has the authority to determine the meaning and effect of the Treaty, ${ }^{11}$ the principles enunciated by the Court of Appeal in the 1987 case of New Zealand Maori Council v Attorney-General (Lands case) ${ }^{12}$ remain the most compelling and utilised articulation of the content of the Treaty guarantee. ${ }^{13}$ These principles are derived from the fact the Treaty signifies a

4 Geoffrey Palmer and Matthew Palmer Bridled Power: New Zealand's Constitution and Government (4 ed, Oxford University Press, Melbourne, 2004) 333-4; Office of Treaty Settlements Ka tika ā muri, ka tika $\bar{a}$ mua: Healing the past, building a future (Office of Treaty Settlements, Wellington, 2004) 11 [Red Book].

5 Treaty of Waitangi, art 2. Note: this is not exactly the text used in the original Treaty of Waitangi, but has been adapted slightly to modern usage.

6 Hugh Kawharu Waitangi: Maori and Pakeha Perspectives of the Treaty of Waitangi (Oxford University Press, Auckland, 1989) 319-20.

7 Treaty of Waitangi, art 1.

8 Kawharu, above n 6, 319-20. See for example Peter Shand "Fixing Settlement: An Analysis of Government Policy for Settling Tiriti Grievances" (1996-1999) 8 Auck ULR 739.

$9 \quad$ New Zealand Maori Council v Attorney-General [1987] 1 NZLR 641, 663 (CA) Cooke P [Lands case].

10 See Robin Cooke "Introduction" (1990) NZULR 14.

11 Treaty of Waitangi Act 1975, s 5.

12 Lands case, above n 9, 704 Casey J.

13 See Judge Carrie Wainwright "The Lands Case 20 Years On: Its Influence on the Waitangi Tribunal" (In Good Faith Symposium, Dunedin, 29 June 2007) 2 ["Influence on the Waitangi Tribunal"]; Jacinta Ruru "Treaty of Waitangi Principles 20 Years On" [2007] NZLJ 87. Other versions of the Treaty principles have been articulated, including the publication of five principles by the Labour Government in 1989, see Palmer and Palmer, above n 4, 334-336. Within the Treaty settlement process the Office of Treaty Settlements has also set out a number of specific principles by which it is guided in its work: Red Book, above n 4, 30 . 
relationship "akin to partnership". ${ }^{14}$ They include: a fiduciary duty on the part of the Crown (which results in the obligation of active protection), full spirit of co-operation, upholding the honour of the Crown, and the provision of fair and reasonable redress. ${ }^{15}$

\section{NEGOTIATION AND SETTLEMENT PROCESS}

\section{A Creation of the Waitangi Tribunal}

During the 1960s and 1970s New Zealand saw the rise of a generation of protestors who sought to bring Māori indigenous rights to the forefront of national attention. ${ }^{16}$ The resulting increase in national awareness of Māori issues combined with a number of other factors present at the time to force the government to acknowledge the issues of Māori and take action. ${ }^{17}$

The creation of the Waitangi Tribunal in 1975 heralded a new phase of more responsive government. It was initially formed to only deal with contemporary claims. The Tribunal was to hear claims by any Māori individual or group that any action by the Crown had resulted, or would result, in a breach of the Treaty of Waitangi. ${ }^{18}$ Despite the fact that few recognised its significance at the time, the creation of the Waitangi Tribunal was a watershed moment; the beginning of a journey towards a society that placed much greater value on Māori issues. ${ }^{19}$ Whether one saw the creation of the Tribunal as a constructive path forward, or simply a "pressure-reducing valve", ${ }^{20}$ the Tribunal was an important acknowledgement that "all was not well".

From these relatively understated beginnings through until 1982, the Tribunal did very little, and therefore was given very little attention by both Māori and government. ${ }^{21}$ It was not until 1985 that

14 Lands case, above n 9, 704 Casey J.

15 Ibid, 664-6 Cooke P.

16 Known as the Māori Renaissance. See E Taihakurei Durie and Gordon S Orr "The Role of the Waitangi Tribunal and the Development of a Bicultural Jurisprudence" (1990) 14 NZULR 62, 62; Claudia Orange An Illustrated History of the Treaty of Waitangi (Bridget Williams Books, Wellington, 2004) 136-7.

17 Orange, ibid.

18 Treaty of Waitangi Act 1975, ss 5 and 6; Hon M Rata (10 September 1975) 401 NZPD 4342-4346.

19 Durie and Orr, above n 16, 144.

20 Judge Carrie Wainwright "What is the Job of the Waitangi Tribunal (And Other Questions...)" (Waitangi Tribunal Conference, NZLS Conference, 17-18 November 2005) 3 ["What is the Job of the Waitangi Tribunal?"].

21 There were only two reports released by the Waitangi Tribunal before 1982: Waitangi Tribunal Fisheries Regulations Hawke Report: Wai 1 (Department of Justice, Wellington, 1978); Waitangi Tribunal Report of the Waitangi Tribunal on the Waiau Pa Power Station Claim: Wai 2 (Department of Justice, Wellington, 1978). See Richard P Boast "The Waitangi Tribunal: "Conscience of the Nation", or Just Another Court?" (1993) 16 UNSWLJ 223, 226; Richard Boast and Deborah Edmunds "The Legacy of Maori Council and the Struggle for Redress: Perspectives from Practice" (In Good Faith Symposium, Otago University, 29 June 
the Tribunal was given the jurisdiction to hear claims arising from 1840 onwards. It was with that jurisdictional extension (and contemporaneous amendments to the nature and extent of the Tribunal's administrative functions) that it became the body recognisable today. ${ }^{22}$ The Tribunal became a body empowered to "propose a bicultural approach to lawmaking and administration and to the formation and delivery of public policy and services." 23

\section{B Creation of the Settlement Process}

The creation of a specialist Tribunal, now with retrospective jurisdiction, was a clear acknowledgement of the legitimacy of the historical claims of Māori. By doing this the Crown had now completely opened the Pandora's box that is the Treaty of Waitangi, whereas previously the lid had only been given fleeting and intermittent moments ajar. It was quickly evident that the Crown did not intend to leave the process of reconciliation to simple compliance with Waitangi Tribunal recommendations. Already two large iwi were in negotiations with the Crown (Ngāi Tahu and Tainui), and the fisheries settlement was to be signed in $1992 .{ }^{24}$ It was essential that the Crown formulate a process whereby the claims reported on by the Tribunal could be settled, and the grievance that was being aired could be healed.

Such a process was developed by a group of Crown officials during the early 1990s, culminating in the release of the now infamous Crown Proposal for the Settlement of Treaty of Waitangi Claims in $1994 .{ }^{25}$ The proposal was heavily condemned by Māori, not least for the inclusion of the "fiscal envelope" - a proposal to set a one billion dollar cap on the total available funds for settlement of claims. ${ }^{26}$ Much of the criticism focused on the process by which the government developed the policy. It was developed in a "climate of secrecy and unilateral declaration" which undermined the good faith and partnership foundations essential to a meaningful settlement process. ${ }^{27}$ Despite these

2007); Mason Durie Te Mana, Te Kāwanatanga: The Politics of Māori Self-Determination (Oxford University Press, Melbourne, 1998) 185 [Te Mana, Te Kāwanatanga].

22 Treaty of Waitangi Amendment Act 1985; (6 August 1985) 465 NZPD 6059-6084.

23 Durie and Orr, above n 16, 62.

24 Te Mana, Te Kāwanatanga, above n 21, 188; see (6 August 1985) 465 NZPD 6059-6084 (Hon K T Wetere, Mr Peters and Mr Graham in particular).

25 Office of Treaty Settlements Crown Proposal for the Settlement of Treaty of Waitangi Claims: Detailed Proposal (Office of Treaty Settlements, Wellington, December 1994). See Te Mana, Te Käwanatanga, ibid, $188-89$.

26 See Office of Treaty Settlements Report of Submissions: Crown Proposals for the Treaty of Waitangi Claims (Office of Treaty Settlements, Wellington, December 1995); Te Mana, Te Kāwanatanga, ibid, 19094.

27 M H Durie and S Asher "The Hirangi Hui: A Report Concerning the Governments Proposal for the Settlement of Treaty of Waitangi Claims and Related Constitutional Matters" (Hirangi Marae, Turangi, 28 
criticisms the policy was implemented without substantial amendment, ${ }^{28}$ although notably the fiscal envelope was officially abandoned. ${ }^{29}$ The settlement process is now managed by the Office of Treaty Settlements (OTS), ${ }^{30}$ which negotiates all claims on behalf of the Crown. The Office is overseen by the Minister in Charge of Treaty of Waitangi Settlements. Within the field of executive action, the negotiation process is relatively unique in that it is guided solely by a policy statement and absent any controlling legislation. The current policy statement, Ka tika à muri, ka tika à mua: Healing the past, building a future (Red Book) was released in 2004. Although extensive at first glance, it is in fact an incomplete guide to the negotiation process. Many gaps exist and some areas are vague and uncertain, creating a process that is far from transparent and accessible. ${ }^{31}$

The initial vision was of a settlement process that would work in tandem with the Waitangi Tribunal, with claimants going into negotiations once Tribunal investigation was complete. This has not proven to be the reality, with many claimants opting for the "direct negotiations" path, sidestepping the Tribunal process altogether. The original intention to combine the two processes is evident in the fact that the OTS still requires claimants to have a claim lodged with the Waitangi Tribunal before it will begin pre-negotiation discussions.

The settlement process is focused on a number of important milestones that claimants and the Crown work towards. Where no Tribunal report exists, the initial steps may take longer as more research is required. Aside from this, there is very little difference between the direct negotiations path and entering negotiations after receiving a Waitangi Tribunal report. The main steps are as follows: ${ }^{32}$

a. Register claim with Waitangi Tribunal

b. Establish large natural group

c. Mandate

d. Terms of Negotiation

January 1995) 4. See Shand, above n 8, 751; Craig Coxhead "Settlement of Treaty Claims: Full and Final, or Fatally Flawed?" (1997) 17 NZULR 13, 24.

28 John H Roberts Politics not Justice: The Government's Treaty Settlements Policy (Joint Methodist Presbyterian Public Questions Committee, Wellington, 1999) 6; Shand, above n 8, 751; Coxhead, above n $27,25$.

29 Red Book, above n 4, 87.

30 Established as a separate unit of the Ministry of Justice in 1994.

31 See generally Crown Forestry Rental Trust Māori Experiences of the Direct Negotiation Process (Crown Forestry Rental Trust, Wellington, 2003); Coxhead, above $\mathrm{n} 27$.

32 See Red Book, above n 4. 
e. Agreement in Principle

f. Deed of Settlement

g. Ratification

h. Implementation (legislation)

This is not the place to expound in detail the positive and negative aspects of the settlement process, despite the unfortunate lack of informed academic commentary on the topic. ${ }^{33}$ However, it is important to acknowledge and provide some background to the mounting discontent with the Treaty settlement process. It is this background that explains the increase in the number of cases being brought and Waitangi Tribunal reports being released on the process.

\section{Main Criticisms}

Criticisms of the Treaty settlement process and OTS centre on (but are not limited to) a small number of key issues. The first of these is the Crown's policy of only negotiating with large natural groups. This policy provides that in order to ensure the most time and resource-efficient settlements, the Crown will only accept "large natural groups" into negotiations. ${ }^{34}$ The policy was adopted internally after the formulation of the 1994 policy, and as a result has never been open for consultation. ${ }^{35}$ Furthermore, no definitive definition of a "large natural group" has ever been provided by the Crown. There is increasing concern that as a result of this policy smaller iwi, hapu and whānau will be prejudiced, ${ }^{36}$ either by their claims being subsumed into those of the larger grouping who do not effectively represent their interests, or by potentially missing out on the opportunity to have their claims settled with the Crown at all. ${ }^{37}$ Such prejudice will create further grievances which one day will also need to be confronted. ${ }^{38}$ Such a policy of the amalgamation of

33 The commentary that does exist is largely of exemplary quality. See Mãori Experiences of the Direct Negotiation Process, above n 31; Annie Mikaere "Settlement of Treaty Claims: Full and Final, or Fatally Flawed?" (1997) 17 NZULR 425; Coxhead, above n 27; Shand, above n 8.

34 See Red Book, above n 4, 44; Office of Treaty Settlements "Baseline Review of the Office of Treaty Settlements (OTS)" (20 November 2001) 12 (Obtained under the Official Information Act 1982 Request to the Director, Office of Treaty Settlements); Office of Treaty Settlements "Paper to Maori Affairs Committee Re: Speeding up of Historical Treaty Settlements" (8 October 2002) (Obtained under the Official Information Act 1982 Request to the Director, Office of Treaty Settlements).

35 Malcolm Birdling "Healing the Past or Harming the Future? 'Large Natural Groupings' and the Treaty Settlement Process" (LLB(Hons) Research Paper, Victoria University of Wellington, 2003) 12.

36 Roughly translated, an iwi is a tribe, a hapū a subtribe, and whānau is a family unit. See generally Angela Ballara Iwi: The Dynamics of Māori Tribal Organisation From c. 1769 to c. 1945 (Victoria University Press, Wellington, 1998).

37 Birdling, above n 35, 20.

38 Ibid. 
claims is particularly concerning in light of the increasing academic commentary that states that it is hapū rather than iwi that form the basis of Māori society. ${ }^{39}$ Furthermore, many of these concerns have been acknowledged internally by OTS and other government departments, and yet the policy continues to be followed. ${ }^{40}$

Second are mandate issues. The security of negotiating bodies' mandates has proven a significant ongoing issue for the Treaty settlement process. This is partly as a result of the large natural group policy forcing whānau and hapū into groups that are often far from "natural", and partly as a result of issues inherent in Māori tribal relations. From the early Tainui and Ngāi Tahu settlements, to the most recent Te Arawa Kaihautu Executive Council (KEC) settlement (Te Arawa settlement), mandate has proved a significant issue. ${ }^{41}$ The criticisms, as they relate to Crown action, largely centre on questions of whether the Crown has ensured that all groups the mandated body purports to represent have in fact given their support and authority to the body to settle their claims. Criticism of the manner in which the Crown has dealt with mandate issues has been particularly forceful in the Te Arawa settlement. There have now been three inquiries into the KEC's mandate, each increasingly critical of the Crown's approach and responses. ${ }^{42}$

Possibly the most difficult aspect of the settlement process, and the most concerning area of Crown failure, is the process of dealing with those iwi who are not in negotiations with the Crown where their interests overlap with the interests of a settling group. Groups can suffer considerable prejudice as a result of the settlement of a neighbouring group's claims. Earlier settlements determine the availability of assets and resources to settle surrounding claims. Fluid and changing tribal histories combined with a non-exclusive understanding of cultural interests in land mean that in many areas of New Zealand multiple tribal groups have cultural interests in land and sites of significance. ${ }^{43}$ A settlement that fails to recognise a group's interests in a site may result in an

39 Ballara, above n $36,19$.

40 Office of Treaty Settlements "Completion of Historical Treaty Settlement Process: Strategic Overview" (February 2004) CBC (04) 23 (Obtained under the Official Information Act 1982 Request to the Director, Office of Treaty Settlements); Te Puni Kōkiri "Completion of Historical Treaty Settlement Process: Strategic Overview: Te Puni Kōkiri's Response" (3 February 2004) TP1115/4 (Obtained under the Official Information Act 1982 Request to the Director, Te Puni Kōkiri).

41 Greensill and others v Tainui Maori Trust Board (17 May 1995) HC HAM M117/95; Waitaha Taiwhenua o Waitaki Trust v Te Runanga o Ngai Tahu (17 June 1998) HC CHCH CP41/98; Waitangi Tribunal Te Arawa Mandate Report: Wai 1150 (Legislation Direct, Wellington, 2004) [Te Arawa Mandate Report]; Waitangi Tribunal Te Arawa Mandate Report: Te Wahanga Tuarua: Wai 1150 (Legislation Direct, Wellington, 2005) [Te Arawa Mandate Report: Te Wahanga Tuarua]; Waitangi Tribunal Report on the Impact of the Crown's Settlement Policy on the Te Arawa Waka: Wai 1353 (Legislation Direct, Wellington, 2007) [Te Arawa Waka]; Fenwick v Trustees of Nga Kaihautu o Te Arawa Executive Council (13 April 2006) HC ROT CIV 2004-463-847.

42 Footnote 41 above; Part IV C Subject-Matter of Claims; Te Arawa Waka, above n 41, 195 and 225.

43 Ballara, above n 36. 
unrepresented iwi, hapū or whānau losing access to culturally significant sites. This has proven a considerable issue for the Crown, the extent of which was never foreseen. In 2007 alone, two extremely critical reports on the Crown's overlapping claims process were released. ${ }^{44}$ Each clearly illustrates the Crown's failure to understand the cultural implications of the settlement process on overlapping claimants and Māori society. The reports concluded the current process to be incapable of dealing with the individual circumstances before them: ${ }^{45}$

Because of the connections between all of the people, and all of their connections to the land, dealing with all of the interests well is subtle and challenging work. It involves the Office of Treaty Settlements team forming relationships not only with those who are settling but also with those who for the time being are not. It is vital that this part of the settlement process is done well, but for the most part it seems to us that it is not being done at all.

The Crown's process of dealing with overlapping claimants has developed in the last seven years as a response to various Tribunal reports. Yet as these recent reports illustrate, the steps taken have been insufficient to allay the fears of many Māori. ${ }^{46}$

Of most concern to Māori, and more generally to those concerned with the effectiveness of New Zealand's political and legal accountability mechanisms, is the sense of déjà vu that is creeping into OTS failures and Treaty settlement process issues. Te Arawa is the most commanding example of this. With four Waitangi Tribunal reports into this one settlement the Tribunal was able to clearly discern a sustained attitude of disregard for Waitangi Tribunal recommendations which led to yet further issues for the Te Arawa settlement. ${ }^{47}$ In the Tamaki Makaurau Settlement Process Report (Tamaki Makaurau) the Tribunal reviewed all previous reports into the overlapping claims process and was greatly disappointed to discover that "[i]t appears that the approach of the Office of Treaty Settlements has not changed materially from those earlier cases to the present one." 48

\section{WAITANGI TRIBUNAL AS A REVIEW MECHANISM}

Once it has been conceded that there are serious issues in the current Treaty settlement process it becomes necessary to decide in which fora these issues should be explored. Clearly there are the

44 Te Arawa Waka, above n 41; Waitangi Tribunal The Tamaki Makaurau Settlement Process Report: Wai 1362 (Legislation Direct, Wellington, 2007) [Tamaki Makaurau].

45 Tamaki Makaurau, ibid, 2.

46 Ibid, 9. See Part V E Impact Analysis. See generally Māori Party "Maori Party says the Time has Come" (15 June 2007) Press Release.

47 Te Arawa Waka, above n 41, 33.

48 Tamaki Makaurau, above n 44, 9. 
judicial and political forums familiar to all countries; however New Zealand is relatively unique in having a well-established forum solely dedicated to hearing issues raised by its indigenous people. ${ }^{49}$

Hendrik Hartog recognised the "problematic relationship between our social pluralism - the multiplicity of our social practices and normative identities - and the values we impute to legal order." 50 Social pluralism, or the co-existence of multiple identifiable cultures, is an issue that extends past colonial nations. Combined with issues of indigeneity, however, it poses complex questions for society. Courts are ill-equipped to deal with cultures and belief systems alien to them. A resulting criticism of the courts providing remedies for indigenous peoples is that they are based in a legal system and set of practices that are inherently foreign to those indigenous people. Forcing indigenous peoples to fit their claims and grievances within the context of the dominant power's legal system and law is to perpetuate the process of colonisation: ${ }^{51}$

For [indigenous peoples] the law has acted as a vehicle of totalization, colluding with a power that demanded constraint, delimitation, definition, demarcation. Aboriginal rights have become an elaborate juridical doctrine that legitimates these processes

The Waitangi Tribunal is one unique example of an attempt to deal with the issues of social pluralism, and to create an arena in which culturally-specific claims may be heard. The influence of informed and culturally sensitive chairpersons, such as Judge Durie and the current Chairperson Judge Williams, has created a forum which is explicitly self-aware and overtly conscious of the need to make itself relevant to those seeking a voice within it. ${ }^{52}$

\section{A Nature of the Waitangi Tribunal}

The nature of the Tribunal continues to be a matter of some debate, but it is generally acknowledged to be equal to a permanent Commission of Inquiry which falls within a relatively flexible para-legal process. ${ }^{53}$ As a Commission of Inquiry the Waitangi Tribunal has the ability to

49 There are forums in other countries dedicated to particular aspects of the process of hearing and settling indigenous claims. Some of these forums are called "tribunals". However, none of these equate to the Waitangi Tribunal in purpose, function or jurisdiction. Most are largely administrative and do not take part in the substantive investigation and determination of claims. Some Pacific island nations are currently at various stages of implementing bodies modelled on the Waitangi Tribunal.

50 Hendrik Hartog "Pigs and Positivism" [1985] Wis L Rev 900, 902.

51 Peter Kulchyski Unjust Relations: Aboriginal Rights in Canadian Courts (Oxford University Press, Toronto, 1994) 1.

52 Richard Boast "Waitangi Tribunal Procedure" in Janine Hayward and Nicola R Wheen (eds) The Waitangi Tribunal: Te Roopu Whakamana $i$ te Tiriti o Waitangi (Bridget William Books, Wellington, 2004) ["Waitangi Tribunal Procedure"].

53 E T J Durie "The Waitangi Tribunal: Its Relationship with the Judicial system" [1986] NZLJ 235, 235; "Waitangi Tribunal Procedure", ibid; R P Boast "Lawyers, Historians, Ethics and the Judicial Process" (1998) 28 VUWLR 87. 
adopt more flexible procedures which are more relevant to the sensitive and diverse matters which it is asked to inquire into. ${ }^{54}$

The Waitangi Tribunal is constituted under the Treaty of Waitangi Act 1975. Section 5 of the Act provides that the Tribunal is to inquire into and make recommendations on claims, having regard to, and with the authority to interpret, the two texts of the Treaty of Waitangi. Claims may be made by any Māori person and can be about a broad range of things from ordinances and Acts of Parliament, through to any act or omission by the Crown. ${ }^{55}$ As a result of the broad definition of its jurisdiction, the Tribunal is able to inquire into a much wider range of issues than the courts.

Following from the well known case law surrounding the move in the 1980s towards privatisation of government assets, the Treaty of Waitangi Act was amended in 1988. ${ }^{56}$ The Waitangi Tribunal now had the power to make binding recommendations in respect of state-owned assets, forestry and some railways land. ${ }^{57}$

\section{B Contemporary Inquires}

Some surprise has been expressed at the recent upsurge in the Tribunal's contemporary jurisdiction. Despite the predominance of historical inquiries, the Waitangi Tribunal was originally set up to deal with contemporary claims. ${ }^{58}$ Therefore criticisms that the Tribunal is unreasonably stretching the boundaries of its designated purpose to deal with contemporary claims are misconceived. Contemporary inquiries are of increasing importance: with the inevitable conclusion of the Tribunal's historical function it seems unavoidable that contemporary inquiries will increasingly define the Tribunal's purpose and functions. ${ }^{59}$ Furthermore, the relationship between the processes of Waitangi Tribunal investigation and that of negotiation and settlement of claims is

54 Durie and Orr, above n 16, 65.

55 Treaty of Waitangi Act 1975, s 6. "Māori" is defined in section 2 as "a person of the Māori race of New Zealand; and includes any descendant of such a person." The main things the Tribunal may not inquire into are bills currently before Parliament.

56 Treaty of Waitangi (State Enterprises) Act 1988.

57 Treaty of Waitangi Act 1975, ss 8A-8HJ.

58 Treaty of Waitangi Act 1975, s 6(6) (original 1975 text); "Influence on the Waitangi Tribunal", above n 13, 2; "What is the Job of the Waitangi Tribunal?", above n 20, 3.

59 Some of the contemporary claims coming before the Waitangi Tribunal are incredibly comprehensive and complex, and in many cases their broad reach or controversial subject-matter leads to them being particularly high-profile. Most notable are the Report on the Crown's Foreshore and Seabed Policy and the complex and comprehensive Wai 262 or Flora and Fauna inquiry which completed hearings in June 2007. 
much more contentious that it appears at first glance. The Waitangi Tribunal provides an ongoing incentive for the Crown to ensure the smooth and durable settlement of claims. ${ }^{60}$

In recent years the Waitangi Tribunal has found itself overwhelmed with applications for urgency inquiries into various aspects of the Crown's settlement policy and practice. These inquiries have culminated in a number of reports, the most recent of these receiving considerable public and political attention. ${ }^{61}$ Two of the reports released in 2007 went as far as to recommend that the Crown halt the settlements with the relevant groups. ${ }^{62}$

Acknowledging the overwhelming number of urgent claims being made, the Acting Chairperson of the Waitangi Tribunal convened a judicial conference on 22 November 2006 to discuss the possible co-ordination of the various inquiries. ${ }^{63}$ At the conference it became clear that there was strong support for a broad generic inquiry into the Crown's settlement policy. ${ }^{64}$ This was ultimately rejected by the Tribunal in favour of the continuation of more specific inquiries into particular settlements of concern. ${ }^{65}$ The Tribunal felt that many of the issues were region-specific and feared prejudice to individual claimants if their claims were heard within a broad inquiry. ${ }^{66}$ It is likely that they were also motivated by concerns of separation of powers and not overstepping the bounds of their jurisdiction.

One advantage of the Waitangi Tribunal is its technical expertise and experience in Māori land claims. As the Tribunal itself points out, to examine the reasonableness of cultural redress decisions made by the Crown it is occasionally necessary to make an independent evaluation of the

60 See discussion of the recently filed remedies application of Ngāti Tuwharetoa: Part V D Judicial Impact Analysis.

61 Waitangi Tribunal Pakakohi and Tangahoe Settlement Claims Report: Wai 759 and 142 (Legislation Direct, Wellington, 2000); Waitangi Tribunal Ngati Maniapoto/Ngati Tama Settlement Cross-Claims Report: Wai 788 and 800 (Legislation Direct, Wellington, 2001); Waitangi Tribunal Ngāti Awa Settlement Cross-Claims Report: Wai 958 (Legislation Direct, Wellington, 2002); Waitangi Tribunal Ngāti Tuwharetoa ki Kawerau Settlement Cross-Claims Report: Wai 996 (Legislation Direct, Wellington 2003) [Tuwharetoa Cross-Claims Report]; Te Arawa Mandate Report, above n 41; Te Arawa Mandate Report: Te Wahanga Tuarua, above $\mathrm{n}$ 41; Tamaki Makaurau, above n 44; Te Arawa Waka, above n 41; Waitangi Tribunal Final Report on the Impact of the Crown's Treaty Settlement Policy on the Te Arawa Waka and Other Tribes: Wai 1353 (Legislation Direct, Wellington, 2007) [Te Arawa Waka Final Report].

62 Tamaki Makaurau, ibid; Te Arawa Waka Final Report, ibid.

63 Memorandum of the Acting-Chairperson, Waitangi Tribunal (19 October 2006).

64 Memorandum of Counsel on behalf of Ngati Hikairo, Tamahaki Incorporated Society, Uenuku Tuwharetoa and Ngati Rangitihi (21 November 2006). A great deal of further support was given by other claimants' counsel in oral submissions, however no transcript was kept therefore there is unfortunately no reference to direct readers to.

65 Memorandum of the Acting-Chairperson, Waitangi Tribunal, above n 63.

Ibid, 11. 
substantive value of claimant's interests in a particular site. ${ }^{67}$ The experience Tribunal members cultivate in historical inquiries means that they are well-placed to deal with such issues and make such technical pronouncements.

However, the Tribunal often seeks to avoid answering these technical and resource-intensive questions in the course of Treaty settlement inquiries. ${ }^{68}$ To do so would be impossible within the limitations of an urgency inquiry and would defeat the purpose of the Tribunal's carefully scheduled historical inquiry process. As a result of the reluctance to investigate substantive issues of entitlement, Treaty settlement inquiries often closely resemble judicial review proceedings. The reports show a high level of scrutiny of Crown decision-making processes. Often this analysis is framed in terms such as reasonableness, good faith, fairness, impartiality and natural justice. ${ }^{69} \mathrm{In}$ each case the assertions made by claimants are largely centred on the failure of the Crown to follow appropriate procedure. ${ }^{70}$ Other assertions rest on claims that the Crown had acted unreasonably and without good faith. ${ }^{71}$

What distinguishes the principles of the Treaty of Waitangi from these broader legal ones are their foundation. Modern interpretation of the Treaty of Waitangi is centred on the unique "living relationship" between the New Zealand Crown and Māori. ${ }^{72}$ Consequently, the expectations that rest on the Crown and Māori derive from concepts of partnership and equality, rather than looking to general administrative ideals or fundamental human rights. Outcomes are to be reached through a good faith process of engagement and collaboration. It is the lack of this sense of partnership in the Treaty settlement process that raises the most serious concerns: ${ }^{73}$

We were dismayed, in Tamaki Makaurau, to see how little sign there was of any of these questions being resolved with any sense of partnership. The tone and style of the Crown's interaction was uniformly that of the decision-maker: the Crown holds all the cards, and pack is mostly hidden, and then the Crown tells everyone how the hand will be played.

67 Te Arawa Waka, above n 41, 48.

68 See generally ibid, 12.

69 In the recent Te Arawa inquiry the Crown took this as far as to plead that the Tribunal's power to investigate was limited to matters of procedure and policy, and it was unable to inquire into the quality of substantive decisions: Closing Submissions on Behalf of the Crown (3 April 2007) Wai 1353, Doc \# 3.3.32, para 4 ["Crown Submissions"].

70 "Amended Submissions of Counsel for Ngāti Rangitihi" (Wai 996) (23 March 2007) Wai 1353, Doc \# 3.3.24 ["Submissions for Ngāti Rangitihi"].

71 Ibid, para 6; "Statement of Issues" (15 January 2007) Wai 1353, Doc \# 2.5.28, Issue 2.2.

72 Te Arawa Waka, above n 41, 34.

73 Tamaki Makaurau, above n 44, 56. 
It is this that makes the obligations owed to a Treaty partner higher than those owed to other stakeholders - further distinguishing the Treaty of Waitangi from the principles of good administration. Because the focus is a living relationship, the ideal is that the Treaty's rights and corresponding obligations can be more "flexible, practical, and natural". ${ }^{74}$

\section{Subject Matter of Claims}

As a process-based area of review, the Treaty settlement inquiries within the Waitangi Tribunal fit much more closely into the traditional conception of administrative law than conventional Tribunal inquiries do. Rather than looking into the substantive nature of Crown actions, these inquiries often focus on investigation of the processes followed by the Crown within individual settlement negotiations.

The recent Report of the Impact of the Crown's Settlement Policy on the Te Arawa Waka (Te Arawa Waka) and Final Report of the Impact of the Crown's Treaty Settlement Policy on the Te Arawa Waka and Other Tribes (Te Arawa Waka Final Report) examined the Crown's actions in negotiating the Te Arawa settlement. This agreement was negotiated with the KEC and is the largest settlement since Ngāi Tahu. ${ }^{75}$ The release of these two reports means that there are now a total of four reports by the Waitangi Tribunal into aspects of this particular settlement. Furthermore, there has been High Court action over the KEC's mandate, ${ }^{76}$ and the forestry aspects of the inquiry have been the subject of (thus far unsuccessful) litigation in the High Court and Court of Appeal. ${ }^{77}$

The inquiry focused broadly on the following areas: overlapping claims, mandate, geothermal redress, and the forestry redress policy. The former three relate directly to the broader discussion of the areas of concern with the Treaty settlement process above. ${ }^{78}$ The issues raised about the forestry redress, while falling broadly into the category of overlapping claim concerns, are unique issues resulting from the agreement negotiated after the New Zealand Māori Council and Federation of Māori Authorities' challenge to the Crown's devolution of Crown assets in the late 1980s. ${ }^{79}$ The

74 Ibid, 34; Lands case, above n 9, 642 Cooke P.

75 Te Arawa Waka, above n 41; Te Arawa Waka Final Report, above n 61; "Crown Submissions", above n 69 , para 10.2.

76 Fenwick v Trustees of Ngā Kaihautu o Te Arawa Executive Council, above n 41.

77 New Zealand Maori Council v Attorney-General (4 May 2007) HC WN CIV-2007-485-95; New Zealand Maori Council v Attorney-General [2007] NZCA 269. As at writing the claimants had sought leave to appeal to the Supreme Court: "Notice of Application by First and Second Appellants for Leave to Bring Civil Appeal" to the Supreme Court of New Zealand (30 July 2007) in the case of New Zealand Māori Council v Attorney-General.

78 See Part III C Issues with the Process.

79 Lands case, above n 9; New Zealand Māori Council v Attorney-General [1989] 2 NZLR 142 (CA). See generally Janet McLean "New Public Management New Zealand Style" in Paul Craig and Adam Tomkins The Executive and the Public Law: Power and Accountability in Comparative Perspective (Oxford 
focus of the forestry redress claim was that if the Crown was to take the accumulated rentals held for successful claimants by the Crown Forestry Rental Trust (CFRT) for itself, it would be breaching an agreement negotiated in trust and good faith. In doing so the Crown would directly profit from a breach of the Treaty of Waitangi. A further criticism was that the process would potentially prejudice other claimants as it would lead to an increased amount of land being granted to settling groups, resulting in less forestry land available for iwi entering negotiations later on. ${ }^{80}$

In its separate report into the forestry issues, the Waitangi Tribunal held: ${ }^{81}$

We have no objection in principle to any mechanism which allows the Crown to offer a more generous settlement to claimants, provided always that the interests of groups outside the negotiations are protected. We would add that at the point that deferred selection over CFL lands was included in the offer to the KEC, the Crown must have known that the area of land which the KEC would be able to acquire would more than double, given the value of the accumulated rentals. Thus, the duty of the Crown to actively protect the interests of all groups with overlapping interests was increased, particularly as every hectare of CFL land in the pool was subject to overlapping claims. The highest standard of consultation with overlapping groups would be required, to communicate the complexity of the deal on offer, and to allow the groups to ensure that their interests were not prejudiced in the process.

The Tribunal also held that the Crown's actions were insufficient to meet its burden of active protection: ${ }^{82}$

In our view, for the Crown to include this provision in the deed of settlement is inconsistent with the Treaty. To make matters worse, the Crown failed to communicate this proposal to the other parties to that agreement (the NZMC and the FOMA), to the CFRT itself, to the claimant groups who might otherwise have received benefits from those rentals, and indeed to the general public.

The situation created by the Crown's proposed actions in breach of the 1989 agreement is unique and illustrates the complexity of the issues that the Treaty settlement process raises. Any nonpolitical body faced with such questions is put in the rather dire position of having to examine the Crown's actions in what ultimately becomes part of the political and legislative process. All settlements are implemented through legislation, and therefore even where the Crown proposes

University Press, Oxford, 2005) 125-160 ["New Public Management New Zealand Style"]; Palmer and Palmer, above n 4, 109-117; Matthew Palmer "The State-Owned Enterprises Act 1986: Accountability?" (1988) 18 VUWLR 169; Nicola White "NZ Maori Council \& Latimer v Attorney-General \& Others" (1988) 6 AULR 119; R P Boast "New Zealand Maori Council v Attorney-General: The Case of the Century?" [1987] NZLJ 240.

80 Ngāti Rangitihi "Closing Submissions Regarding Commercial Redress for Ngati Rangitihi" (4 July 2007) Wai 1353, Doc \# 3.3.63.

81 Te Arawa Waka Final Report, above n 61, 39.

82 Ibid, 42. 
action that would breach an agreement affirmed in previous legislation, parliamentary sovereignty provides the shield behind which the Crown may hide. Nonetheless, when faced with such a proposition, surely the Crown's decision to take action breached a previous good faith agreement should be reviewable, and the rights of the negotiating partner protected. The forestry concerns raised by the Te Arawa settlement are an emotive example of the issues that claimants are seeking review of in this area.

Forestry claims also brought life to another aspect of the Tribunal's jurisdiction: the power to make binding recommendations. This power was largely a dormant force, having only been used once prior. ${ }^{83}$ Suddenly the Central North Island (CNI) Tribunal (Wai 1200) found itself inundated with applications for binding recommendations over the forests within the CNI inquiry district. In response, the Chairperson Judge Wainwright directed counsel to provide submissions on the content of the Tribunal's jurisdiction in this area. Such was the degree of the unknown inherent in the territory being entered. A list of extensive criteria was established for the Waitangi Tribunal by which to process remedies applications. But despite this, all remedies applications were adjourned sine die as a result of the success of the CNI Collective process, discussed in more detail below.

\section{Judicial Impact Analysis}

A Tribunal with a unique and culturally relevant voice means little if that voice is not heard and heeded. In order to establish whether this is occurring, it is first necessary to establish the framework in which Crown responses are to be reviewed

A recent branch of judicial review study has emerged and become known as the "judicial impact" line of administrative study. ${ }^{84}$ This examines the impact of administrative decisions both within the political science sphere of social and political change, and within the socio-legal sphere of the strength of the law to control governmental power. ${ }^{85} \mathrm{~A}$ beneficial analysis of the Tribunal and courts' work can be produced using the judicial impact framework.

Waitangi Tribunal investigation into the Treaty settlement process is a relatively new development, with the first report being released in 2000. Although important contemporary claims have been heard throughout the Tribunal's history, recent reports such as The Petroleum Report, Report on the Crown's Foreshore and Seabed Policy and the Wai 262 or Flora and Fauna claim have been highly contentious and received a new level of political scrutiny. That is not to say that

83 Waitangi Tribunal The Turangi Township Remedies Report: Wai 84 (Legislation Direct, Wellington, 1995).

84 Marc Hertogh and Simon Halliday "Introduction" in Marc Hertogh and Simon Halliday (eds) Judicial Review and Bureaucratic Impact: International and Interdisciplinary Perspectives (Cambridge University Press, Cambridge, 2004) 1-2. Also see Carol Harlow and Richard Rawlings Administrative Law (2 ed, Butterworths, London, 1997) 565-73; R Rawlings "Judicial Review and the "Control of Government"" (1986) 64 Pub Adm 125.

85 Hertogh and Halliday, ibid, 2. 
past reports have not been high-profile or contentious, as clearly claims such as Radio Spectrum, Te Reo and Muriwhenua Fisheries were extremely high profile. Rather, the more recent reports have been the high-profile claims of a new political era, and therefore have faced challenges different from those of their predecessors. Within the Treaty settlement context it is only very recently that the trends or patterns resulting from this new political era have become apparent.

It is essential that the objectives and purpose of review be understood at the outset. This requires a decision to be made about whether administrative review is aimed at outcomes for the individual applicant, or whether it attempts to address systematic bureaucratic failure. ${ }^{86}$ Protection of irreplaceable cultural interests is fundamental and its importance should never be understated. However, the bigger issue is repeated systematic failure within bureaucratic decision-making. The Waitangi Tribunal can only have a lasting effect and prevent future prejudice to Māori by remedying these larger, recurring failures. It is therefore within this framework that the Crown's response will be reviewed.

Any discussion of review in the Waitangi Tribunal is inevitably influenced by the jurisdictional and formal limitations on the Tribunal's powers. Except in very limited circumstances, its powers are solely recommendatory. ${ }^{87}$ Recommendations can be general or specific, ${ }^{88}$ and reports will often include a mixture of both: incorporating general principles alongside specific recommendations to be implemented. ${ }^{89}$ As a result of the non-binding character of its recommendations, the impact of Tribunal decisions rests largely on the credibility and political weight of the reports.

86 Peter Cane "Understanding Judicial Review and Its Impact" in Hertogh and Halliday, above n 84, 15, 32.

87 Treaty of Waitangi Act 1975, s 5 and 6. A historically less utilised incentive is the Waitangi Tribunal's power to hold a remedies hearing from which it can make binding recommendations in respect of existing and former state owned enterprises land and forests. Such a recommendation has been made only once, and the response from the government was swift, negotiating an alternative settlement to ensure only minimal lands were ultimately "clawed back" from private ownership. However, as a result of increasing dissatisfaction with the negotiation and settlement process, increasing pressure is being placed on the Tribunal to convene remedies hearings and utilise this power. The "risk" of the Tribunal convening such a hearing has been acknowledged internally by OTS: Office of Treaty Settlements "Baseline Review of the Office of Treaty Settlements (OTS)" (20 November 2001) 6 (Obtained under the Official Information Act 1982 Request to the Director, Office of Treaty Settlements). However, this paper will not look at the binding recommendatory power in any great deal as it falls outside of the scope of the discussion at hand.

88 Treaty of Waitangi Act 1975, s 6(4).

89 There has been a change in the nature of Tribunal reporting, most likely as a result of the increased dominance of the Treaty settlement process. Earlier reports were more likely to make specific recommendations, whereas more recently the Tribunal has stopped after making findings of breach and more general recommendations, leaving details of redress to be negotiated between the Crown and the particular claimants. 
Harlow and Rawlings argue that the overriding function of "public law is the control of abuse of power". ${ }^{90}$ This is particularly true within the context of Waitangi Tribunal review. Its focus on the protection of the inherent rights of an indigenous minority means there is a considerable power imbalance in favour of the Crown. Much litigation and many Tribunal inquiries in the past have been centred on attempts to stop Crown actions that would breach Treaty guarantees. This was particularly true during the 1980 s when the state was rapidly changing. Māori feared that the devolution of control over state enterprises would result in the loss of significant rights and resources. ${ }^{91}$ However, recent Waitangi Tribunal inquiries have become centred on a more facilitative role that better fits within the "green light theory" proposed by Harlow and Rawlings. ${ }^{92}$ The aim of these inquiries is to "facilitate legitimate government action". ${ }^{93}$ The issue with the settlement process is that its unilateral development has created a process that has an inherent lack of transparency. It is inflexible, and at times extremely difficult to navigate. ${ }^{94}$ Therefore, ironically, adversarial litigation in the Tribunal has become the last resort for Māori seeking more meaningful engagement and dialogue with the Crown in the settlement process.

The non-binding nature of its recommendations means that in order to be effective the Tribunal is forced to work within a green light framework. The Tribunal and the Crown must actively engage and work towards constructive solutions. It is essential that both parties are committed to the process and recognise the importance and credibility of the other. In some areas simply the process of airing grievances can achieve these goals, as Crown officials are given the opportunity to hear and understand the grievances of Māori. ${ }^{95}$ However, this is only successful where officials are already open and responsive to such concerns. In reality, to portray the Waitangi Tribunal as a separate and autonomous branch of review is misleading. The Waitangi Tribunal's effectiveness

90 Harlow and Rawlings, above $\mathrm{n} 84,25$. See also Louis L Jaffe and Edith G Henderson "Judicial Review and the Rule of Law: Historical Origins" (1956) 72 LQR 345, 346. But see Paul Craig and Adam Tomkins "Introduction" in Craig and Tomkins, above n 79, 8-14. Contrast H W R Wade and C F Forsyth Administrative Law (8 ed, Oxford University Press, Oxford, 2000) 4-5; P P Craig Administrative Law (Sweet \& Maxwell, London, 2003) ch 1.

91 In particular the various New Zealand Māori Council cases dealing with the State Owned Enterprises legislation and policies; see Part IV C Subject-Matter of the Claims.

92 See Harlow and Rawlings, above n 84, 67-90.

93 Ibid, 71.

94 Coxhead, above n 27, 24 and 26-27; Māori Experiences of the Direct Negotiations Process, above n 31, 60.

95 An example of this is the response of Karen Sewell of the Minister of Education to the issues raised in the Wai 262 hearings, and in public submissions, to the omission of any references to the Treaty of Waitangi in the recently released Draft National Curriculum: Transcript of Cross-Examination of Karen Sewell, Ministry of Education (26 January 2007) Waitangi Tribunal, Wai 262, 369; Māori Party "Māori Party Celebrates Treaty Restored to Education" (14 March 2007) Press Release www.scoop.co.nz (accessed 27 September 2007) 
rests on the efficacy of the political process. The achievement of real outcomes depends almost entirely on the existence of a political will to implement Tribunal recommendations. If the Tribunal is seen as out of touch with reality, its recommendations can easily be swept aside with little political consequence.

In some areas Tribunal recommendations appeared to have led to fundamental changes in Crown policy. As a result of recommendations in the Tuwharetoa ki Kawerau Cross-Claims Report OTS began to consult with cross-claimants once the Terms of Negotiation were completed rather than waiting until the Agreement in Principle has been finalised. ${ }^{96}$ However, as subsequent inquiries have shown, a change in policy does not necessarily equate to a change in practice, leading to concerns about the value of such responses.

Many of the Tribunal's recommendations are implemented at the most basic of levels and in a manner that demonstrates minimal engagement by the Crown. The Te Arawa Mandate Report recommended the Crown reconfirm the mandate of the KEC. ${ }^{97}$ This was done by OTS as requested. However, it was done within very specific boundaries and led to no broader policy analysis. Further recommendations of the Tribunal regarding individual claimants were explicitly rejected by Crown officials who stated that the recommendations were given with "little analysis" and "did not respond to the Crown's evidence". ${ }^{98}$ As a result, the claimants were back in the Tribunal within a few months of the release of the report. ${ }^{99}$

It became apparent in the most recent Te Arawa inquiry that OTS had failed to advise the Minister on all recommendations made by the Tribunal in its 2005 Te Arawa Mandate Report: Te Wahanga Tuarua. This has since been conceded by Crown officials to be a serious mistake. ${ }^{100}$ Such actions illustrate a disregard for the value of Tribunal recommendations within administrative decision-making. Rather than facilitating positive developments in government action, bureaucratic disregard for the decisions has undermined the potential value of the inquiry process. A lack of adequate internal reporting processes disables any potential consideration or dialogue before it could begin. This illustrates the failure of the Waitangi Tribunal process to meet the expectations of the "green light theory".

96 Tuwharetoa ki Kawerau Cross-Claims Report, above n 61; Briefing Paper to the Minister in Charge of Treaty of Waitangi Negotiations from the Office of Treaty Settlements (14 August 2003) 48/NE18 06200 02, para 22 (Obtained under Official Information Act 1982 Request to Director, Office of Treaty Settlements).

97 Te Arawa Mandate Report, above n 41, 113.

98 Briefing Paper to the Minister in Charge of Treaty of Waitangi Negotiations from the Office of Treaty Settlements (12 August 2004) 39/CLA-TR-01-081-02, para 32 (Obtained under Official Information Act 1982 Request to Director, Office of Treaty Settlements).

99 Te Arawa Mandate Report: Te Wahanga Tuarua, above n 61.

100 "Crown Submissions", above n 69, para 18. 
Disregard for Tribunal recommendations is shown throughout the briefing papers provided to the Minister. Comments from officials repeatedly reinforce the tense nature of the relationship between the Tribunal and OTS. In one briefing to the Minister, OTS officials stated: ${ }^{101}$

In our view, the Tribunal has set the bar too high in terms of its perception of the Crown's obligations to cross-claimants and the steps that the Crown should take to meet those obligations. Its observations seem to be symptomatic of a limited understanding of the work and time that is required for negotiations, the difficulties of engaging with cross-claimants, and the pragmatic balancing exercise that is required between the interests of the settling group and those of cross-claimants.

In relation to one recommendation, OTS officials expressed serious concerns about issues of practicality: ${ }^{102}$

The Tribunal's suggestion for according priority status to Ngāti Makino, Waitaha, and Tapuika and a cluster around Ngāti Whakaue raises a number of significant implications in respect of Crown strategy, policy and resourcing....

However, not all Tribunal recommendations have received such outright rejection from officials. There are examples of more constructive engagement with recommendations that officials saw as problematic: ${ }^{103}$

The Crown generally avoids making judgements as to which groups are tangata whenua. We would be reluctant to notify territorial authorities that Ngāti Rangitihi are tangata whenua at Matata. We consider it reasonable to notify territorial authorities that Ngāti Rangitihi people live at Matata, and that provision has been made for Ngāti Rangitihi ... to receive cultural redress of the same or similar kind to Ngāti Awa and Ngāti Tuwharetoa as part of a Treaty settlement.

Nonetheless, despite such examples of constructive engagement, more often OTS responses illustrate that although OTS strives to create a perception of acquiescence to Waitangi Tribunal decisions, Crown officials far from see themselves as bound by the recommendations made. They question whether Tribunal members have the necessary capabilities and understanding. ${ }^{104}$ Broadly

101 Briefing Paper to the Minister in Charge of Treaty of Waitangi Negotiations (30 March 2005) 296/CLA-TR01-081-02, para 14 (Obtained under Official Information Act 1982 Request to Director, Office of Treaty Settlements) Annex A, para 21.

102 Ibid, para 14.

103 Ibid, para 14.

104 Potentially, as the volume of urgency inquiries continues to increase, individual Tribunal members and judges beginning to specialise in these types of inquiries may continue to increase the quality and credibility of Tribunal reports in this area. 
speaking the Crown has attempted to acknowledge and implement the recommendations. But on closer analysis their responses often fall more accurately into the category of non-acquiescence. ${ }^{105}$

Such precedents create an interesting background when considering how the Crown has responded and will respond to the recent highly critical Te Arawa Waka and Tamaki Makaurau reports. The Crown's actions in this area have been drawn directly into the public eye by these reports. ${ }^{106}$ With this much public attention, meaningless surface conformity is no longer possible. After the release of the Te Arawa Waka Final Report on 30 July 2007 there existed a great deal of uncertainty as to how the government would respond. ${ }^{107}$ In the past publicity has not stopped the Crown from ignoring Tribunal recommendations and pursuing its desired policy. Examples of such conduct can be seen in Crown rejection of both the Report on the Crown's Foreshore and Seabed Policy and The Petroleum Report. This sets a concerning precedent and illustrates a dramatic decline in the political impact of the Tribunal.

Tribunal recommendations are limited, not because of their recommendatory nature, but rather because of the issues inherent in judicial investigation of executive functions. Officials do not see themselves as bound by recommendations when they feel that these recommendations evidence a lack of understanding of executive constraints. In order for the Tribunal's recommendations to be of greater force the public engagement that was historically important in the Tribunal process needs to be reinvigorated. ${ }^{108}$ If Tribunal recommendations are given more public credibility then there will be greater pressure on officials to further engage with recommendations that they see as practically difficult to implement, because the decisions will carry more political capital. Recent public interest in the Treaty settlement process and the subsequent government response is an indication that this revitalisation has begun. Whether it will result in the considerable changes necessary to effectively protect Māori interests is yet to be seen.

\section{E CNI Collective and the Forests}

In response to the Te Arawa Waka Final Report the Government announced that it would delay the introduction of the Te Arawa settlement legislation until the Crown had met with concerned

105 See the three ways government agencies can respond to judicial decisions: Bradley C Canon "Studying Bureaucratic Implementation of Judicial Policies in the United States: Conceptual and Methodological Approaches" in Hertogh and Halliday, above n 84, 79-95.

106 See Yvonne Tahana "Tribunal Wants Tribes to Sort out Forestry Settlement" (2 August 2007) New Zealand Herald www.nzherald.co.nz (accessed 26 August 2007).

107 "Government Pushes on with Treaty Deal Over Forests" (17 August 2007) New Zealand Herald www.nzherald.co.nz (accessed 25 August 2007).

108 Regarding the decline in the public element of Tribunal inquiries see R P Boast "The Waitangi Tribunal and Transitional Justice" (VUW Cross-Campus Symposium, Contemporary Human Rights in Perspective, Wellington, 23 August 2006) 7. 
Central North Island iwi and discussed their concerns. ${ }^{109}$ When discussing the reasons for the delay, Rt Hon Dr Michael Cullen stated: ${ }^{110}$

It has never been the Crown's intention to become the ultimate beneficiary of these funds and we have stated that the funds would be used for Maori development. I am leading work considering how this can be best achieved.

It was agreed "that providing other iwi in the region with the opportunity to discuss their concerns with the Crown will ultimately benefit all in the region." 111 However, at the same time the Crown reiterated its "commitment to honour the Crown settlement offer". ${ }^{112}$

This response was received with a degree of scepticism. The Waitangi Tribunal had boldly said that it "cannot endorse the KEC settlement in its current form" and it recommended "that the proposed settlement be varied and delayed pending the outcome of a forum of CNI iwi convened by Te Puni Kōkiri." 113 The Crown's response clearly showed that it was unwilling to vary the Te Arawa settlement. While it was engaging in a form of dialogue with the CNI claimants, many felt that the worth of this engagement was likely to be limited while the Crown refuses to compromise on the foundational issue - the inclusion of the deferred selection of forestry assets in the Te Arawa settlement. Was the Crown creating simply yet another forum for affected iwi to voice their concerns, rather than a place in which a constructive solution could be forged?

The overwhelming lack of faith in the Crown's promise was evidenced in the surge of urgent remedies applications filed with the Waitangi Tribunal asking it to use its power to make binding recommendations over forestry assets. ${ }^{114}$ The applications state that the matter has become one of urgency as a result of the imminent implementation of Te Arawa settlement from which they will suffer prejudice. ${ }^{115}$ This is a clear rejection of the Crown's offer of dialogue and indicates an acute lack of faith in the Crown's engagement with the concerns of overlapping claimants in this area.

109 Hon Mark Burton "Affiliate Te Arawa Iwi and Hapu Settlement Legislation" (24 August 2007) Press Release.

110 Ibid.

111 Ibid.

112 Ibid.

113 Te Arawa Waka Final Report, above n 61, 68.

114 Ngā Hapū o Ngāti Tuwharetoa "Application for Resumption of Licensed Land Pursuant to s 8HB of the Treaty of Waitangi Act 1975" (18 September 2007) Wai 1200 ["Application for Resumption"]; Ngā Hapū o Ngāti Tuwharetoa "Memorandum of Counsel in Support of Application for Resumption" (18 September 2007) Wai 1200.

115 "Application for Resumption", ibid, 2. 
The motivational relevance of these applications to the Crown is unclear, but there is no doubt that they were a relevant concern. It cannot be doubted that the Crown had a strong interest in avoiding the use of the Waitangi Tribunal's binding powers.

Slowly but surely a number of key successes have swayed many iwi who initially refused to participate. The Collective and the Crown signed a Terms of Agreement setting out the terms of the ongoing relationship. ${ }^{116}$ Since then the Collective has presented to the Crown a proposal outlining the method by which the CNI forests shall be divided amongst the various claimants. ${ }^{117}$ The agreement has gained a high degree of support from the Maori involved. Groups that had previously remained outside the CNI Collective, such as Ngati Raukawa and Ngati Manawa, joined and began working for a dialogue-based solution.

As the most important outcomes are those that relate to the development and improvement of bureaucratic processes, ${ }^{118}$ significant value could be obtained if the CNI Collective was able to develop a precedent that would prevent further breaches and allow for more effective processes in the future. Even where individual recommendations are not heeded, it is the Crown's response to the broader concerns about its policy and processes that is of fundamental importance. It appears that more heartening progress is being made than many initially believed likely. However, cynical as it may be, one cannot be too surprised by a sudden upsurge in political action during an election year. The recent transfer of the portfolio to Dr Michael Cullen has seen a major change in the handling of Treaty settlements. Dr Cullen has taken a much more hands-on leadership role, reminiscent of National's Doug Graham. What is concerning is that this is a pace that cannot be sustained. Dr Cullen's forceful approach may result in great benefits for some claimant groups, in the form of immediate and very generous settlements. The risk of such a single-minded focus is that the Waitangi Tribunal and the next government will be left with the aftermath of claimants who have suffered with no chance to have their voice heard in a much condensed overlapping claims process. Very little could be offered by a Waitangi Tribunal faced with a number of groups whose interests have been steamrolled over in pre-election haste. Further, once again this is a process that very much "picks winners", as the groups who will gain the government's attention prior to the election are those large cohesive groups with whom a settlement equates to generous political capital. The Collective defines itself as an "Iwi Collective", excluding smaller unrepresented hapu within the area.

116 Terms of Agreement Between the Minister of Charge of Treaty of Waitangi Negotiations and Tumu Te Heuheu, Ngati Rangitihi, Ngai Tuhoe, Ngati Tuwharetoa, Ngati Whakaue and Ngati Whare (22 February 2008).

117 Michael Cullen "Central North Island Proposal a Positive step" (4 April 2008) www.beehive.co.nz (accessed 27 April 2008); Central North Island Iwi Collective "Forest Land Settlement Proposal Presented" (5 April 2008) www.scoop.co.nz (accessed 27 April 2008).

118 See Part IV E Judicial Impact Analysis. 


\section{PLACE OF THE COURTS}

It is slightly strange to ask what the place of the courts is in the review of the Treaty settlement process, as the courts themselves have repeatedly declared that they do not have a place. Nonetheless, the negotiation and settlement process has been plagued with litigation and controversy ever since its inception in the late 1980s and early 1990s. The failure of the politics to provide any meaningful response, combined with the ineffectiveness of review in the Waitangi Tribunal causes claimants to persevere in their attempts to draw the courts into the Treaty settlement "battleground". Despite these attempts the courts have maintained a hard-line refusal to engage, and continue to invoke the assistance of non-justiciability in order to maintain their "Swedish neutrality".

\section{A Courts' Statements of Non-Justiciability}

The determinative case in establishing that the Treaty settlement process is non-justiciable was that of Milroy $v$ Attorney-General (Milroy). ${ }^{119}$ There the Court of Appeal held: ${ }^{120}$

But where the action challenged does not itself affect the rights of any persons and is undertaken in the course of policy formulation preparatory to the introduction to Parliament of legislation, the courts will not intervene. Proposed legislative conduct of the Crown said to depart from a previous stance and to be inconsistent with Treaty rights may be within the jurisdiction of the Waitangi Tribunal and may be the subject of representations to the Select Committees of Parliament. But, as Goddard J said, the courts cannot help.

As this shows, the Court not only held that there was no relevant head of jurisdiction, ${ }^{121}$ it also made it clear that it considered all such challenges non-justiciable as they fell within the bounds of conduct preparatory to the introduction of legislation. Milroy built on the foundation established by Te Runanga o Wharekauri Rekohu Inc v Attorney-General (Sealords), where the Court of Appeal originally pointed to the fact that "[t]here is an established principle of non-interference by the Courts in Parliamentary proceedings." 122

The courts' issue with the questions that claimants raise is the inherently political nature of much of the content. This can be seen from the early case of Greensill v Tainui Maori Trust Board (Greensill): ${ }^{123}$

119 Milroy v Attorney-General [2005] NZAR 562 (CA).

120 Ibid, para 18 Gault P for the Court.

121 Ibid, para 10 .

122 Te Runanga o Wharekauri Rekohu Inc v Attorney-General [1993] 2 NZLR 301 (CA), para 15 Cooke P for the Court. See generally Peter Cane Administrative Law (4 ed, Oxford University Press, Oxford, 2004 ) 47.

123 Greensill v Tainui Maori Trust Board, above n 41, 12 Hammond J. 
I do not see how it can be said that this is anything other than a political document. And on that basis this Court should be extremely cautious about intervening. I do not say that a Court could never intervene in a document having some political characteristics... But I am clear that the Court should not do so here.

Ultimately this matter will have to be finally resolved where it should be resolved - in Parliament.

Hammond J's arguments are on one level accurate: a settlement is an inherently political process involving many highly political and polycentric decisions. One cannot deny the complexity of the decisions that are made in this area. Direct interference by the court in such decisions would often equate to "interference in the political process", 124 and therefore would be contrary to the foundational constitutional doctrine of separation of powers. The motive for defending such separation in the Treaty settlement context is best expressed by Goddard $\mathrm{J}$ in Pouwhare v AttorneyGeneral: 125

[The non-justiciability of this claim] is because the decision under challenge in each case is a policy decision, reached as the result of a negotiated settlement process which has received the imprimatur of Cabinet approval. Further, notwithstanding that Cabinet approval, the decision is still in the nature of a preliminary decision and subject to Parliamentary scrutiny before any necessary legislation implementing settlement [sic] can be enacted.

However, while this justification may be correct in relation to certain elements of the claims being made, it does not justify the courts' refusal to intervene in all cases. To understand this it is necessary to look closer at the concept of non-justiciability.

\section{B Theory of Justiciability}

The most commonly cited New Zealand definition of non-justiciability comes from the case of Curtis v Minister of Defence (Curtis): ${ }^{126}$

A non-justiciable issue is one in respect of which there is no satisfactory legal yardstick by which the issue can be resolved. That situation will often arise in cases into which it is also constitutionally inappropriate for the Courts to embark.

Justiciability is a test of whether an issue is one that is properly suited to adjudication in the courts, or put more broadly, about "where public decision-making should best reside". ${ }^{127}$ It is a

124 Watene v Minister in Charge of Treaty of Waitangi Negotiations (11 May 2001) HC WN CP 120/01, para 33 Goddard J.

125 Pouwhare v Attorney-General (30 August 2002) HC WN CP78/02, para 7 Goddard J

126 Curtis v Minister of Defence [2002] 2 NZLR 744, para 27 (CA) Tipping J for the Court.

127 B V Harris "Judicial Review, Justiciability and the Prerogative of Mercy" (2003) 62 CLJ 631, 634. 
screening device that allows for a "'big picture' constitutional appreciation of whether or not the decision is an appropriate one for the courts." 128

To ensure consistency, certainty and clarity, the factors relevant to an assessment of appropriateness within justiciability must be fleshed out. Many feel uncomfortable with the concept that the courts are the judge of what matters they can and should adjudicate on, citing the maxim nemo judex in re sua (no man should be the judge of his own cause) as evidence of the undesirability of such an approach. ${ }^{129}$ Justiciability is a troublesome concept and a potential "forum for tension between judicial restraint and judicial activism." ${ }^{130}$ Therefore, in order to maintain the credibility of the courts' discretion, it is necessary that the test applied be as transparent as possible. ${ }^{131}$

One of the earliest cases on justiciability is the English case of Council of Civil Service Unions $v$ Minister for the Civil Service (CCSU). ${ }^{132}$ There it was not necessary for the House of Lords to expound in any great detail the factors relevant to non-justiciability, as the area under consideration - national security - was clearly outside the scope of the Court's jurisdiction. ${ }^{133}$ However, as more difficult cases have come before the courts, three broad factors to be considered have been espoused: the capacity and legitimacy of the judicial process, the constitutional principle of separation of powers, and nature of the issues being considered. ${ }^{134}$ The factors have been articulated in other ways but this is one is the most practically useful. ${ }^{135}$

The first of these factors, capacity, includes fundamental practical considerations such as the availability of resources and the suitability of the issues to determination through an adjudicative, adversarial process of dispute resolution. ${ }^{136}$ The quote from Curtis is directly relevant here: ${ }^{137}$ in

128 Ibid, 633.

129 Ibid, 634

130 Ibid, 635 .

131 For a discussion of the question whether justiciability should be used as a screening mechanism at all see Chris Finn "The Justiciability of Administrative Decisions: A Redundant Concept?" (2002) 30 Fed L Rev 239.

132 Council of Civil Service Unions v Minister for the Civil Service [1985] AC 374 (HL) [CCSU].

133 Ibid, 397 Diplock J.

134 Lorne M Sossin Boundaries of Judicial Review: The Law of Justiciability in Canada (Carswell, Scarborough, 1999) 2 [Boundaries of Judicial Review].

135 Also see Harris, above n 127. The effect of these different articulations is practically minimal as the same things ultimately fall to be considered.

136 See Lon Fuller "The Forms and Limits of Adjudication" (1978) 92 Harv L Rev 353.

137 See above n 126. 
order to effectively deal with the case at hand the courts must have some appropriate legal yardstick against which to measure the claim. If the claim is wholly unsuited to determination through the adjudicative process, such a legal yardstick will often be absent.

The question of legitimacy is broader and refers to the idea that within our constitutional structure the courts are not always the appropriate place to raise and resolve an issue: "the courts may not be the appropriate body, or be suitably equipped in all contexts to carry out the decisionmaking which judicial review would ideally ask of them." 138 This combines practical considerations such as the experience and capacities of judges with constitutional factors such as the boundaries set by the principle of separation of powers, discussed below. It also requires a clarification of the role of the judiciary: is the judiciary a body concerned solely with simple dispute resolution between individual parties, or does it have a larger constitutional role in espousing and protecting public values? ${ }^{139}$ If the courts have a broader role in the protection of public values such as fundamental human rights and the protection of minorities then there is a much stronger obligation on them to hear claims that touch on elements of policy and political issues. Conversely, if their role is simply limited to that of dispute resolution between individual parties about issues that directly affect those particular parties and not others, then the courts should be more deferential when issues are of a polycentric or political nature. ${ }^{140}$ The answer to this is found in one's understanding of the practical implications of separation of powers.

Separation of powers is the well known basis of our constitutional system whereby each of the three branches of government has their own function and must not encroach on the functions of the other branches: ${ }^{141}$

Parliament will set the framework of general rules for society, the executive will govern within those rules and an independent judiciary will resolve disputes over the meaning of those rules and will, in particular, keep the executive within the boundaries of the law.

It flows from this that the courts have an obligation to check that the executive acts within its constitutional boundaries, including ensuring respect for inherent human and indigenous rights. ${ }^{142}$ Nevertheless, it is essential that the judiciary respect the boundaries of its jurisdiction and not

138 Harris, above n 127, 633.

139 Boundaries of Judicial Review, above n 134, 3; "New Public Management New Zealand Style", above n 79. 131-35; David Dyzenhaus "The Politics of Deference: Judicial Review and Democracy" in Michael Taggart (ed) The Province of Administrative Law (Hart Publishing, Oxford, 1997) 279.

140 See Harris, above n 127, 635.

141 Martin Loughlin Public Law and Political Theory (Clarendon Press, Oxford, 1992) 145. Also see Sossin, above n 134, 8-20; Jaffe and Henderson, above n 90, 346.

142 It is acknowledged that the existence of 'inherent human rights' has historically been a contentious issue: $\mathrm{J} A$ G Griffith "The Political Constitution" (1979) 42 MLR 1. 
encroach on that of the executive and, in particular, the democratically elected Parliament. This is especially relevant in light of the fact that the judiciary is not elected and therefore is not directly representative or accountable. Respect for boundaries must be balanced with an appreciation of the significant benefits the courts can offer as an independent accountability mechanism. ${ }^{143}$ Furthermore, many commentators who support the concept of legal constitutionalism point to the fact that the courts are in fact indirectly accountable to the people as a result of the need for sustained public confidence and credibility. ${ }^{144}$

As well as answering the questions posed regarding legitimacy, separation of powers seeks to enforce boundaries based in the source of the power exercised by the decision-maker. Rather than looking at the nature of the issue as shall be discussed below, here the court is asked to look at the source of the power that is being reviewed and to question whether it would be contrary to our constitutional structure to use the courts to hold the particular decision-maker accountable. ${ }^{145}$ Over time the importance of the source of a decision-maker's power has gradually diminished, replaced by a focus on the nature of the issues. ${ }^{146}$ It is now generally accepted that in most cases it is the nature and content that determines a matter's justiciability, not its source. ${ }^{147}$

The nature of the issue alludes to a number of variants. As a starting point it must be asked whether it is a monolithic dispute, or one that is inherently polycentric and therefore requires the weighing of many competing interests which affect large sectors of society. ${ }^{148}$ It must be realised "that certain kinds of human relations are not appropriate raw material for a process of decision that is institutionally committed to acting on the basis of reasoned argument." ${ }^{149}$ If the issue is between two individuals and is unlikely to have any consequences beyond those individuals before the court,

143 Harris, above n 127, 637.

144 Ibid, 638; Matthew S R Palmer "Constitutional Realism about Constitutional Protection: Indigenous Rights under a Judicialized and a Politicized Constitution" (2006) 26 Dalhousie L J 1, 25-27.

145 There is a great deal of case law on this point, the most significant distinction being between public and private bodies. It shall not be explored in any detail in this paper, but see $R v$ Panel on Take-overs and Mergers, ex parte Datafin [1987] QB 815 (CA) [Datafin]; Mercury Energy Ltd v Electricity Corporation of New Zealand Ltd [1994] 2 NZLR 385 (PC); Dunne v CanWest TVWorks Ltd [2005] NZAR 577 (HC); Electoral Commission v Cameron [1997] 2 NZLR 421 (CA)

146 See CCSU, above n 132; Datafin, ibid, 828, 847 Lloyd LJ and 850 Nicholls LJ; Electoral Commission v Cameron, ibid, 430 Gault J for the Court.

147 Cane Administrative Law, above n 122, 54; Murry Hunt "Constitutionalism and the Contractualisation of Government in the United Kingdom" in Taggart, above n 139, 28-9.

148 Fuller, above 136. For arguments against the approach taken by Fuller see J W F Allison "Fuller's Analysis of Polycentric Disputes and the Limits of Adjudication" (1994) 53 CLJ 367.

149 Fuller, ibid, 371. 
the court has little reason to refuse to hear the dispute. ${ }^{150}$ However if the decision is of a more polycentric nature, then any decision by the court will have far-reaching consequences, making the decision more like policy formation than adjudicative decision-making. ${ }^{151}$ This means that the dispute itself will be less suited to resolution by judicial inquiry.

Another highly influential element is the political content of the issue. Where issues are highly political and internal to government the courts will rarely intervene because to do so would involve the courts treading into territory where they have limited experience and are not best situated to deal with the issues. ${ }^{152}$

Despite the growing amount of case law and academic commentary on the topic of justiciability, one issue that has not been directly dealt with in much detail is the source of a dispute's nonjusticiability. ${ }^{153}$ Questions have been raised about whether any dispute can be inherently nonjusticiable - particularly in highly political areas such as national security. ${ }^{154}$ But the question remains: when a dispute is non-justiciable is the court declaring that it simply does not have (and therefore never had) jurisdiction to hear the dispute, or, conversely is the court "for some reason [relinquishing] their ordinary constitutional function"? 155 The Court in CCSU seemed to imply that the non-justiciability of the issues before them was something unavoidable and therefore something for which they could not be held accountable as decision-makers: ${ }^{156}$

Once the factual basis is established by evidence so that the court is satisfied that the interest of national security is a relevant factor to be considered in the determination of the case, the court will accept the opinion of the Crown ... unless it is possible to show that the opinion was one which no reasonable minister advising the Crown could in the circumstances have held. There is no abdication of the judicial function, but there is a common sense limitation recognised by the judges as to what is justiciable...

150 Harris, above n 127, 635.

151 T R S Allan Constitutional Justice: A Liberal Theory of the Rule of Law (Oxford University Press, Oxford, 2001) 198 [Constitutional Justice]; Fuller, above n 136, 395-96.

152 Harris, above n 127, 641.

153 See ibid; Geoffrey Marshall "Justiciability" in A G Guest (ed) Oxford Essays in Jurisprudence (Oxford University Press, Oxford, 1961) 265; Boundaries of Judicial Review, above n 134; Finn, above n 131; Lorne Sossin "The Rule of Law and the Justiciability of Prerogative Powers: A Comment on Black v Chrétin" (2001-2) 47 McGill LJ 435; Constitutional Justice, above n 151; Richards LJ "The International Dimension of Judicial Review" (Gray's Inn Reading, Barnard's Inn, London, 7 June 2006); M C Harris "The Courts and Cabinet: 'Unfastening the Buckle'?" [1989] PL 251

154 CCSU, above n 132. See Marshall, above n 153.

155 Constitutional Justice, above n 151, 162.

$156 C C S U$, above n 132, 394 Scarman LJ (emphasis added). 
The importance of this issue lies in the potential limitations on the courts' obligations when declaring an issue non-justiciable. If questions are inherently non-justiciable then the court has no discretion in the matter. Certain matters are simply outside the realm of the courts' jurisdiction and they simply cannot ever deal with those issues. An example of this approach is the "excluded categories" referred to by Lord Roskill in CCSU. ${ }^{157}$ Conversely, if the courts refuse to hear an issue simply because they feel it would be better dealt with in an alternative forum, then the courts have exercised discretion and this requires justification. ${ }^{158}$

The way in which the courts are increasingly intertwining questions of justiciability with the concept of judicial deference implies that the source of non-justiciability is the latter. ${ }^{159}$ Simply put, the courts defer to the political branches of government in recognition of their superior expertise and ability in relation to a particular dispute. ${ }^{160}$ In doing this the court is giving up its inherent power of review. It is reasonable to infer that when choosing to defer to the political branches the court should provide reasons for abdicating its role: ${ }^{161}$

The judiciary cannot, as the legislature may, avoid a measure because it approaches the confines of the constitution. We cannot pass it by because it is doubtful. With whatever doubts, with whatever difficulties, a case may be attended, we must decide it, if it be brought before us. We have no more right to decline the exercise of jurisdiction which is given, than to usurp that which is not given. The one or the other would be treason to the constitution [sic].

The serious consequences of justiciability decisions make it reasonable to expect the courts to justify their decision. Furthermore, it is appropriate to also expect that the courts will ensure that the alternative forum they have deferred to will in fact provide justice to the individual or individuals concerned. It would go against the principle of access to justice if the court could simply defer to the political branch of government when it is clear that the parties' voices will not be heard in that forum. This is particularly true in light of the fact that the courts have held that "[even] when a court is faced with the exercise of a discretionary power, inquiry is not altogether excluded: the court will

157 CCSU, above n 132, 401 Roskill LJ.

158 For a discussion of the concept of "alternative forums" see Marshall, above n 153, 267.

159 For the purposes of this discussion it is unnecessary to determine whether deference is conceived of as an act of subordination or respect: see Dyzenhaus, above n 139, 279.

160 See for example Finn, above n 131, 241. In regards to the question of judicial deference see Carol Harlow "The Political Constitution Reworked" in Rick Bigwood Public Interest Litigation: New Zealand Experience in International Perspective (LexisNexis, Wellington, 2006) 189, 203; Murry Hunt "Sovereignty's Blight: Why Contemporary Public Law Needs the Concept of 'Due Deference'" in Nicholas Bramforth and Peter Leyland Public Law in a Multi-Layered Constitution (Hart Publishing, Oxford, 2003) 337; Dyzenhaus, above n 139.

161 Cohens $v$ Virigina (1821) 19 US 264; 6 Wheat 264, 404 Marshall CJ cited in T R S Allan "Pragmatism and Theory in Public Law" (1988) 104 LQR 422, 422 ["Pragmatism and Theory"]. 
intervene to correct excess of abuse." 162 The importance of the availability of other means of recourse is something that the courts are well aware of and clearly take into account. As for example in Milroy: 163

Proposed legislative conduct of the Crown said to depart from a previous stance and to be inconsistent with Treaty rights may be within the jurisdiction of the Waitangi Tribunal and may be the subject of representations to the Select Committee of Parliament.

The practical availability of these alternative forums is often taken for granted. The availability of alternative forums is particularly problematic where the issues at question involve the protection of human and minority rights. The concern is that to leave the protection of such rights to a democratically elected government opens the possibility for a "tyranny of the majority".

\section{Analysis}

The courts continue to hold that review of the process of Treaty settlements is simply beyond the bounds of their jurisdiction. ${ }^{164}$ The development of the Crown's settlement agreement with a particular iwi is an important and highly contentious area of policy formation. It has considerable fiscal implications as well as impacting heavily on a large number of Crown agencies and public interests. ${ }^{165}$ It is desirable that such decisions remain for the Crown to determine, in order that those with the most experience can consider all of the complex and interconnected issues. This allows Crown officials to assess all the relevant information, listen to a wider range of stakeholders, and engage in a focused and well-resourced process of policy development to facilitate the most informed and balanced outcomes possible. ${ }^{166}$

The issue with the courts' approach is that a lack of detailed analysis of claims brought before it has resulted in the failure of the court to recognise that many of the claims deal with issues peripheral to the inherently political issues of Treaty settlement policy. Hammond $\mathrm{J}$ in Greensill held that "in cases of this kind ... [the court] must stand, not under a portable palm tree, but an umbrella of articulated principle". ${ }^{167}$ It is clear from this that the courts appreciate the need for focused analysis in this area. Rather than constantly erring on the side of caution, the courts should hold at the forefront of their mind the fact that "judicial abnegation of responsibility ... seems quite

$162 C C S U$, above n 132, 393 Scarman LJ (emphasis added).

163 Milroy, above n 119, para 19 Gault P for the Court.

164 See Part V A Courts' Statements of Non-justiciability.

165 Treaty settlements touch on an extremely broad range of issues including environmental and resource management, local authorities, treasury, forestry, agriculture and intellectual property.

166 Harris, above n 127, 641.

167 Greensill v Tainui Māori Trust Board, above n 41, 10 Hammond J. 
inconsistent with the theory of the Rule of Law, which insists that, at least within the realm, all aspects of government are conducted within the law." 168 The courts' outright rejection of Treaty settlement cases as non-justiciable without principled analysis has led to the erroneous amalgamation of claims into this non-justiciable area. Treaty settlement claims are being brought not by the negotiating parties themselves, but by those who are affected by the Crown's settlement with another iwi. What is being challenged is the Crown's process of interaction with those groups who do not have a direct or effective voice in the negotiation process.

On this view it becomes much more difficult for the courts to claim inability to review on the ground that these decisions are non-justiciable. The Waitangi Tribunal has acknowledged that despite the unique Treaty of Waitangi context, the decisions made by OTS remain part of an "administrative process". ${ }^{169}$ To review such interactions would simply be to review the procedures and decision-making processes of the Crown - something the courts are very experienced at doing. The entire area of judicial review is founded on the courts reviewing the decision-making processes of government. The fact that the courts have this power is now widely accepted. While difficulties arise if one takes a narrow ultra vires interpretation of the justification for judicial review, ${ }^{170}$ if a broader common law model approach is taken the courts have the power to review the actions of the executive wherever they appear to be inconsistent with the principles of good administration. ${ }^{171}$ Under the common law model, "[u]nless Parliament clearly intends otherwise, the common law will require decision-makers to apply the principles of good administration as developed by Judges in making their decisions." 172

If ultra vires action is no longer the sole focus of judicial review, review based on the principles of good administration can then extend to areas such as Treaty settlement negotiations where there is no governing statute and the process is controlled entirely by policy and political management. This is consistent with the general trends set by other developments in judicial review, such as the

168 "Pragmatism and Theory", above n 161, 407.

169 Tamaki Makaurau, above n 44, 86.

170 "Unless Parliament clearly indicates otherwise, it is presumed to intend that decision-makers must apply the principles of good administration drawn from the common law as developed by Judges in making their decisions." (Weak Ultra Vires Model): C Forsyth "Heat and Light: A Plea for Reconciliation" in C Forsyth (ed) Judicial Review and the Constitution (Hart Publishing, Oxford, 2000) cited in Philip A Joseph "The Demise of Ultra Vires - Judicial Review in the New Zealand Courts" [2001] PL 354, 357 ["The Demise of Ultra Vires"]. See also "New Public Management New Zealand Style", above n 79, 140-41.

171 "The Demise of Ultra Vires", ibid.

172 Forsyth, above n 170. 
control of the actions of state-owned enterprises and other entities not traditionally considered within the Executive. ${ }^{173}$ Furthermore, the outcomes of such intervention will be largely positive: ${ }^{174}$

The procedural controls of judicial review may limit the executive's flexibility in how it exercises its power without necessarily limiting its ultimate power. Such judicial supervision serves to ensure increased participation and greater transparency in executive decision-making. It is a mechanism by which to call the executive to account.

This must be qualified with a dash of realism. Overlapping claimants are most often challenging the Crown's decision to offer particular sites to the iwi in negotiations. Such challenges go beyond the process by which to the decision is made to the heart of the decision itself. Such decisions are of the nature of policy formation. Nonetheless, such decisions affect other iwi immensely, potentially leading to iwi, hapū or whānau losing access to sites of irreplaceable cultural significance. Ironically, in most cases it is the decision-maker's failure to recognise and take account of the polycentric nature of the issues before them that represents the core of the parties' criticism. The grievance is founded in the failure of the decision-maker to recognise that more than one group's interests must be taken into account in making decisions about settlement redress. This initial failure results in the further omission to take into consideration the prejudice that may be suffered by other claimants as a result of the decision. So while it cannot be denied the claims made do stray onto the shore of the dark waters of political decisions, it remains the process of the decisions that is the focus of the challenge.

Concerns about mandate have been approached in varying ways, and historically many cases were brought against the mandated bodies themselves rather than the Crown. More recent claims brought in the Waitangi Tribunal illustrate a much more process focused approach. They demonstrate concern about the process followed by the Crown when recognising that a group has the mandate to settle the claims of a smaller iwi, hapū or whānau. The central matter is whether in the process of decision-making decision-makers are recognising certain factual considerations. This is both when making their initial decision, and on an ongoing basis where groups attempt to withdraw their support for the mandated representatives. Although less clear-cut than overlapping claim issues, issues of mandate can be framed in process terms without substantially compromising the claimant's concerns. In fact mandate issues may be easier to frame in this way as at their core such claims are about administrative process, and they do not require the determination of claims to substantive rights or interests.

173 As a starting point see "New Public Management New Zealand Style", above n 79; Janet McLean "Intermediate Associations and the State" in Taggart, above n 139, 160; Wellington International Airport v Air New Zealand [1993] 1 NZLR 671 (CA); Mercury Energy Ltd v Electricity Corporation of New Zealand, above n 145; Lumber Specialities v Hodgson [2000] 2 NZLR 347 (HC); Datafin, above n 145.

174 "New Public Management New Zealand Style", ibid, 141 (emphasis in original). 
The vast majority of the cases being brought before the courts actually deal with issues of executive decision-making process. Increasingly claimants are pointing to examples of the Crown not only acting in a manner inconsistent with the principles of good administration, but actually going further and bringing what appear to be well-founded claims that the Crown has acted in bad faith. ${ }^{175}$

Precedents such as Milroy have shaped an "easy-out" for the courts, giving rise to a situation where judges are carrying around this "portable palm tree" of "political process" or "policy formation" and all hope of seeing any further "articulated principle" has been lost. The courts have failed to discern the development that has occurred in the cases that have been brought before them, neglecting to recognise the distinctions between challenges "which essentially involve policy and are subject to a ratification process and the political process", ${ }^{176}$ and those challenges which involve the review of peripheral decisions that are not directly part of the legislative development process. Watene $v$ Minister in Charge of Treaty of Waitangi Negotiations (Watene) is an example of the court failing to make this distinction: ${ }^{177}$

The system that the Crown has established to take account, recognise and protect the hapu and their interests in the proposed settlement and subsequent creation of a governance entity, are the results of a political process involving decisions based on questions of policy and matters requiring political judgment. Such political decisions are not amenable to the supervision of the Court in the absence of clear evidence of fraud or the like. What the plaintiffs essentially seek therefore is to interfere in the political process.

To say the Crown has established a system, but then decline jurisdiction on the ground that it is simply part of the political process is inconsistent. If the Executive has created a process to settle such claims, it is the responsibility of the courts to ensure that the Executive stays within the boundaries it has set. An advertised process creates a legitimate expectation on the part of iwi, hapu and whānau, and the Executive should not be allowed to contravene this expectation without good reason. ${ }^{178}$ To do otherwise would be "unfair and inconsistent with good administration". ${ }^{179}$ In the case of mandating, OTS has advertised its process in the Red Book, through publicly available

175 See for example "Submissions for Ngāti Rangitihi", above n 70.

176 Pouwhare v Attorney-General, above n 125, para 45 Goddard J.

177 Watene v Minister in Charge of Treaty of Waitangi, above n 124, para 33 Goddard J.

178 Schmidt v Secretary of State for Home Affairs [1969] 2 Ch 149 (CA); CCSU, above n 132; AttorneyGeneral (Hong Kong) v Ng Yeun Shin [1983] 2 AC 629 (PC); Philip Joseph Constitutional and Administrative Law in New Zealand (2 ed, Brookers, Wellington, 2001), 250-56. See generally Gabriele Ganz "Legitimate Expectation" in Carol Harlow (ed) Public Law and Politics (Sweet \& Maxwell, London, 1986) 145; Mark Elliot "Legitimate Expectation: The Substantive Dimension" (2000) 59 CLJ 421; Peter Cane "Natural Justice and Legitimate Expectation" (1980) 54 Australian LJ 546.

179 Attorney-General (Hong Kong) v Ng Yeun Shin, ibid, 741 Fraser LJ. 
evidence given in earlier Waitangi Tribunal hearings, and also in separate information provided to claimants who enter discussions with OTS. ${ }^{180}$ Similarly with its policy on overlapping claims, OTS has advertised aspects of its process in the Red Book, extensively expanded on and developed its process in evidence and submissions responding to Waitangi Tribunal reports, and has also provided information to claimants (both those in negotiations and overlapping claimants). ${ }^{181}$ Where information is not available or is inconsistent, as has been an ongoing criticism of the overlapping claims process in particular, concerns arise about transparency, certainty and effective active protection. This raises questions of inconsistency. ${ }^{182}$

There is a failure on the part of the Crown to take into account what cannot be anything other than mandatory relevant considerations where decisions have been made about which sites to include in settlements without informed consideration of overlapping interests. The absence of a statutory source of power should not be a bar to the enforcement of such an obviously fundamental consideration, particularly as OTS has itself recognised the relevance of the protection of the interests of overlapping claimants. ${ }^{183}$

Although the courts cannot look at the weight given to individual considerations, ${ }^{184}$ the assessment of whether a consideration has been taken into account would necessarily involve an evaluation of whether the information relied on was sufficient to inform the decision-maker. ${ }^{185}$ This may extend into an evaluation of natural justice and the right to appropriate and meaningful consultation. Most of the information necessary to make such decisions on an informed basis could only be available to OTS after meaningful consultation with overlapping claimants.

180 Red Book, above n 4, 44-45; Pakakohi and Tangahoe Settlement Claims Report, above n 61; Te Arawa Mandate Report, above n 41; Te Arawa Mandate Report: Te Wahanga Tuarua, above n 41; Te Arawa Waka, above n 41; Te Arawa Waka Final Report, above n 61; Te Puni Kōkiri Treaty Claims and Mandating: Settlement Processes and the Mandate: Volume One (Draft); Office of Treaty Settlements "Treaty Settlement Process - Achieving a Mandate to Negotiate (Presentation to Ngāti Tuwharetoa, Rangiita Marae, 4 October 2003).

181 Red Book, above n 4, 28-32, 91-99; Ngati Maniapoto/Ngāti Tama Settlement Cross-Claims Report, above n 61; Ngāti Awa Settlement Cross-Claims Report, above n 61; Ngāti Tuwharetoa ki Kawerau Settlement Cross-Claim Report, above n 61; Tamaki Makaurau, above n 44. Unfortunately a great deal of the overlapping claims information is provided to claimant groups orally or in material that is confidential as it relates to negotiations so is not publicly available.

182 Tamaki Makaurau, above n 44, 85-86.

183 Red Book, above n 4, 28-32, 91-99.

184 Northern Roller Milling Co Ltd v Commerce Commission [1994] 2 NZLR 747, 754-5 (HC) Gallen J; Constitutional and Administrative Law in New Zealand, above n 178, 796-97.

185 Talley's Fisheries Ltd $v$ Minister of Immigration (10 October 1995) HC WN CP201/93; Smith Kline Beecham (NZ) Ltd v Minister of Health [1992] NZAR 357 (HC). 
Unreasoned declarations that issues are non-justiciable raise serious questions of access to justice. Claimants are refused access to the courts, yet the judges determining this are often applying broad precedents without close analysis of the applicability of the precedents to the claims before them.

\section{Judicial Impact Analysis}

A judicial impact analysis cannot be undertaken here due to the courts' lack of involvement. But the prospect of such an analysis raises the interesting and important question about what a successful judicial review of the Treaty settlement process would seek to achieve. Feldman has broken the techniques of judicial control into three main streams: ${ }^{186}$

(a) Directing. The traditional judicial function of compelling government to adhere to stated legal powers and duties.

(b) Limiting. Establishing the scope of, or setting the limits to the exercise of, discretion. For example, the common law rules against delegation and fettering of powers.

(c) Structuring. Making explicit values or goals which are to guide decision-making. This takes in common law principles of legality such as Wednesbury unreasonableness and the duty to act fairly.

In Treaty settlement litigation the greatest concern is repeated bureaucratic inadequacies resulting in a failure to protect the interests of individuals and groups not (or inadequately) represented at the negotiating table. While directing is important in the short-term, the real benefit of judicial review is the opportunity for the court to structure decision-making around more sustainable and effective processes. ${ }^{187}$ Structuring is the most invasive and controlling form of review, as it seeks to actually alter administrators' day-to-day activities in a prospective manner. ${ }^{188}$ Yet it is also the most effective. In areas such as this where there is evidence of repeated bureaucratic failure it is the only form of redress that will provide ongoing protection from prejudicial Crown actions. As long as this is done in a manner that equates to establishing minimum standards for protection rather than the court actually developing the Crown's policy, then such a judicial response is entirely consistent with concepts such as Parliamentary sovereignty and separation of powers.

\section{CONCLUSION}

As illustrated by this discussion, issues of justiciability are intertwined with constitutional issues and the question of the appropriate place for issues to be reviewed. If the courts refuse to hear a claim on the ground that the issues it raises are non-justiciable, they are implicitly holding that the

186 D Feldman "Judicial Review: A Way of Controlling Government?" (1988) 66 Pub Adm 21, 29-30. Summary version taken from Harlow and Rawlings, above n 84, 568 (italics added).

187 Linked to green light theory review: Harlow and Rawlings, above n 84, 67-90.

188 Feldman, above n 186, 30. 
issues should be determined in another arena (most often the political arena). One must therefore confront the questions raised by Griffith's notion of political constitutionalism: claims to inherent rights are simply political claims and thus should be dealt with in the political arena rather than by an un-elected, unaccountable judiciary. ${ }^{189}$ Flowing from this is the inevitable need to meet head-on the reality that administrative law and politics are closely intertwined and even co-dependent. ${ }^{190}$ Administrative law must respond to the changing conception of the State. The Treaty settlement area is an excellent example of the need for flexibility and a judiciary that is conscious of the requirement of development that is responsive to an ever-changing changing political and social reality. 191

The Treaty of Waitangi context adds a further unique and complex dimension to these debates. If the Treaty is a political compact between indigenous peoples and the Crown, is it appropriate for the courts to be making determinations on the interpretation of this compact? Conversely, surely it is the role of our independent judiciary to protect the interests of minorities, and in particular to protect the inherent rights of Māori as the indigenous peoples of New Zealand?

The argument can and has been made that these are simply "political questions" 192 and therefore should be left to the political forms of accountability. Academics such as Matthew Palmer warn against the judicialisation of issues of indigenous rights: 193

The issues are inherently and intensely political. The demographics and political power of Maori suggest to many New Zealanders that the position of Maori is strong enough that national conversations about these issues should be held in the political arena - between people who understand policy and politics, principle and pragmatism - not judges.

Despite inevitable concern about the foreshore and seabed debate, Palmer argues that it has resulted in positive changes as views were aired and a necessary public debate occurred. ${ }^{194} \mathrm{He}$ argues that it has resulted in a "greater political interest in seeking constructive solutions to Treaty issues." 195 Maybe the response to Palmer's idealism lies in the Government's response to the

189 Griffith, above n 142, 33.

190 Harlow and Rawlings, above $\mathrm{n} 84$.

191 See generally Palmer, above n 144, 25-6.

192 "Political questions" is the American term for issues that are non-justiciable because of their political content.

193 Palmer, above n 144, 34

194 Ibid, 37. Regarding the foreshore and seabed debate see below n 199.

195 Ibid, 37 
criticism in recent Waitangi Tribunal reports. This response will provide significant insight into the ability of New Zealand politics to reach constructive and fair solutions. ${ }^{196}$

The Māori renaissance in the late 1960s and 1970s exposed the political strength of Māori. Demographic trends indicate that the importance of the Māori vote is likely to increase dramatically in coming decades. ${ }^{197}$ Combined with the formation of the Māori Party in 2004, it would appear the Māori voice is of increasing force. On the other hand, the now infamous political response to the case of Ngati Apa $v$ Attorney-General revealed that this force is not as powerful as many envisioned. ${ }^{198}$ There the government unilaterally extinguished all customary rights to the foreshore and seabed and replaced them with a statutory scheme for recognition. ${ }^{199}$ The foreshore and seabed debate illustrated that the political strength of Māori has declined since its height in the 1980s and 1990s. New Zealand's response led commentators who had previously had faith in the New Zealand political process to comment: ${ }^{200}$

\footnotetext{
Healthy relationships require healthy dialogue: honesty, trust, respect, good faith, careful sensitivity, a willingness to apologize when offence is given, and a willingness, eventually, to accept an apology and to move on to a new depth of understanding. This is not what I saw in New Zealand's debate about the foreshore and seabed. It was vituperative and destructive and elements of it were racist. It shook my faith in the ability of New Zealand politics to deal, maturely, calmly and reasonably, with issues of high profile policy and national identity.
}

If attempts in the political arena are unsuccessful, the obvious alternative forum for Māori concerned about prejudice resulting from Crown actions is the Waitangi Tribunal. This is a forum increasingly utilised by Māori to deal with contemporary issues. ${ }^{201}$ However, the weight of Waitangi Tribunal recommendations rests entirely on the credibility of the recommendations and the

196 Particularly if the Supreme Court holds the matter to be justiciable and/or makes highly critical statements about the Crown's policy and actions.

197 Sir Tipene O'Regan "Impact on hapu and iwi: A Ngai Tahu perspective" (In Good Faith Symposium, University of Otago, Dunedin, 29 June 2007); Palmer, above n 144, 32-4.

198 Ngati Apa v Attorney-General [2003] 3 NZLR 643 (SC).

199 Foreshore and Seabed Act 2004; see generally Steven Price "The Tide of History" (9-15 August 2003) The Listener Auckland; Bruce Ansley "Foreshore's Lament" (9-15 August 2003) The Listener Auckland; Grant Powell "A Few Thoughts on Foreshore and Seabed" (12 November 2003) www.converge.org.nz (accessed 5 September 2007); Moana Jackson "Seabed deal plainly not fair to Maori" (19 December 2003) Comment www.arena.org.nz (accessed 5 September 2007); Richard Boast "In re Ninety Mile Beach Revisited: The Native Land Court and the Foreshore in New Zealand Legal History" (1993) 23 VUWLR 145; Paul McHugh "Aboriginal Title in New Zealand Courts" (1984) U Cant LR 235.

200 Palmer, above n 144, 36. Note, from here Matthew Palmer goes to argue that positive developments can nonetheless follow from this debate.

201 "Influence on the Waitangi Tribunal", above n 13. 
extent of political buy-in from those to whom the recommendations are directed. ${ }^{202}$ As shown above, historically such buy-in has been lacking, leaving claimants without an effective remedy. ${ }^{203}$ This leads to anxiety resulting from the Crown's failure to respond to recommendations by an established specialist tribunal. There is also further fear that this illustrates a general lack of responsiveness to Māori concerns about the Treaty settlement process. If Māori are given no opportunity to be heard in the courts, and the recommendations of the Waitangi Tribunal are not being heeded, the issue remains whether Māori can gain an effective remedy where serious breaches of the Treaty of Waitangi occur.

These concerns are reinforced in the failure of other accountability mechanisms put in place to protect Māori. An instance of this is the failure of the Crown to meet its statutory obligations under section 8I of the Treaty of Waitangi Act 1975. Under that provision the Minister of Māori Affairs is obliged to report annually to the House of Representatives on implementation of Waitangi Tribunal recommendations. This is supposed to form an important political accountability mechanism. It is to ensure that serious weight and consideration is given to all recommendations of the Waitangi Tribunal by forcing the Executive to publicly justify its decision to reject a recommendation. Earlier this year it became public that since 1995 the Crown had consistently failed to present a report to the House. ${ }^{204}$ A report was drafted in 2004 but it was not presented to the House. ${ }^{205}$ While an updating report has now been presented to Parliament, it lacks much of the detail of earlier implementation reports and is of little practical use. ${ }^{206}$

This illustrates that it is far from acceptable for the courts to take it for granted that other remedies are available to claimants. The current political climate in New Zealand means that both the Waitangi Tribunal and normal political channels often provide little meaningful recourse for claimants who face potentially irreversible prejudice. It is necessary for the courts to respond to the realities of the political situation and ensure the democratic ideals of access to justice and representation endure in practice. Even if the political arena is considered to be the ideal forum for such issues, the overarching principles of New Zealand's constitution make it imperative that the courts respond to needs being left without alternative redress.

202 See Part IV E Judicial Impact Analysis.

203 See Part IV E Judicial Impact Analysis.

204 (21 June 2007) 640 NZPD 10095. A report was prepared in 1996 and is available at the Parliamentary Library, but it was never presented to the House of Representatives.

205 Ibid.

206 Minister of Māori Affairs "Report of the Minister of Māori Affairs on the Progress Made in the Implementation of Recommendations Made to the Crown by the Waitangi Tribunal for Period January 1995-June 2007" (June 2007); Dr Pita Sharples "Horomia's Report 'noted' as saying nothing" (13 August 2007) Press Release. 
To have the court making judgment calls as to the effectiveness of the political arena and the Waitangi Tribunal is prima facie undesirable within New Zealand's constitutional structure, and therefore such determinations should be reserved for clear cases where claimants are suffering repeated breach through obvious failures to gain redress. This should not become a broad mandate for the court to analyse the government's political response mechanisms. However, Treaty settlement is an example of an area where such determinations could and should be made. The seriousness of the issues raised, combined with the flagrant failure of the political arena to respond, should compel the courts to intervene. The use of litigation by indigenous groups can be an effective means of inducing governmental action. Once a binding judgment is delivered the government can respond with a substantially reduced risk of negative political consequences. ${ }^{207}$ The courts have the power to do this without actually determining the nature of the settlement redress, which is a significant advantage over the use of the Waitangi Tribunal's binding recommendatory powers.

Unquestionably the Treaty of Waitangi will continue to provide New Zealand with difficult and complex questions for some time yet. Many of the issues facing Māori today will continue past the settlement of Treaty claims. Therefore, it remains essential to ask where issues faced by Māori should be aired, and where effective remedies can be sought and provided. Accountability is particularly important in the area of Treaty settlements as flawed processes will result in further prejudice to Māori making the settlement of claims pointless and potentially never-ending.

This article has sought to provide a detailed analysis of the treatment of Treaty of Waitangi settlement claims within the New Zealand context. Despite the fact that there are three main arenas open to Māori, it is clear that some Māori who are suffering very real and lasting prejudice are failing to gain an effective remedy. While the failure of the political arena, and as a result the limited value of the Waitangi Tribunal, leads to very real apprehension and disappointment, the failure of the courts to respond to these cases raises serious concerns about access to justice.

207 Kerry Wilkins "Conclusion: Judicial Aesthetics and Aboriginal Claims" in Wilkins, above n 2, 290. 